Coöperative Extension work in Agriculture and Home Economics, College of Agriculture, University of California, and United States Department of Agriculture coöperating. Distributed in furtherance of the Acts of Congress of May 8, and June 30,1914. B. H. Crocheron, Director, California Agricultural Extension Service. 


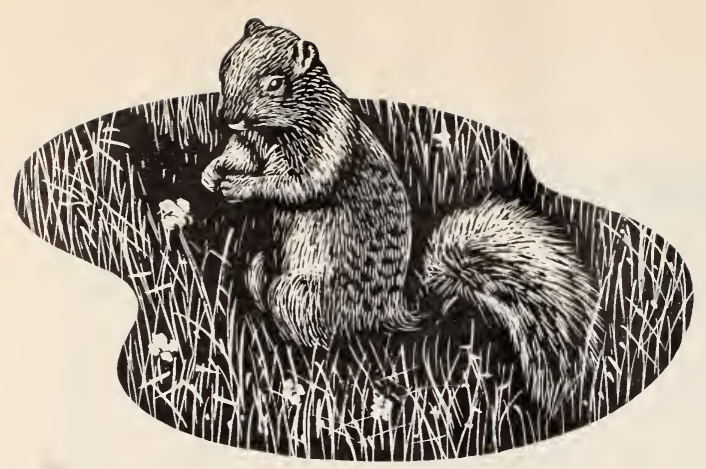

HIS CIRCULAR is intended to aid in the control of field rodents on farms and in home gardens. It describes control methods that have proved successful in the hands of many users. It deals with ground squirrels, tree squirrels, pocket gophers, muskrats, rabbits, meadow mice, and kangaroo rats; also moles. Control of rats and mice in buildings is discussed in another circular.

Damage done by field rodents to agricultural crops amounts to several millions of dollars every year. Moreover, some rodents carry bubonic plague, tularemia, and other serious diseases that may be transmitted to man either directly or by fleas, ticks, or mites.

Effective control is not easy; it involves more than merely setting a trap or scattering some poisoned bait. Good results can be expected only by understanding the habits of the rodent to be controlled, by putting this knowledge to use, and then keeping at control throughout the year so that the number of rodents never becomes large. Hence this circular describes these animals, tells where and how they live, and what they eat.

Control methods include the use of poison baits and poisonous gases, trapping, shooting, exclusion, and encouragement of natural enemies.

Community coöperation will prevent a cleaned area from becoming repopulated by rodents migrating from neighboring infested land.

The poisons used are dangerous to humans and livestock; some of the gases are inflammable or explosive. Precautions in handling and storing are given on page 9 . If accidental poisoning occurs, call a doctor at once.

Help and advice in rodent control may be obtained from any county agricultural commissioner or farm advisor. 


\section{CONTENTS}

\begin{tabular}{|c|c|c|c|}
\hline & & & AGE \\
\hline Why control rodents? .......... & 5 & Tree squirrels . . . . . . . . . . . . . & 25 \\
\hline How to control rodents. . . . . . . . & 6 & Pocket gophers... . & \\
\hline Poison baits $\ldots \ldots \ldots \ldots \ldots \ldots$ & 7 & 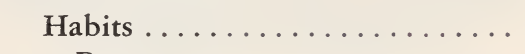 & 27 \\
\hline Strychnine $\ldots \ldots \ldots \ldots \ldots$ & 7 & Burrows $\ldots \ldots \ldots \ldots \ldots$ & 27 \\
\hline e............ & 7 & Breeding . ............ & 28 \\
\hline$\ldots \ldots \ldots \ldots \ldots$ & 8 & Damage by pocket gophers.... & 29 \\
\hline reparations .... & 8 & & \\
\hline Other poiso & 8 & Methods of control $\ldots \ldots \ldots \ldots \ldots$ & 30 \\
\hline Poisonous gases ... & 8 & Trapping $\ldots \ldots \ldots \ldots \ldots \ldots$ & 30 \\
\hline $\mathrm{e} \ldots \ldots \ldots \ldots$ & 9 & ts $\ldots \ldots \ldots \ldots \ldots$ & \\
\hline id gas......... & 9 & gases...$\ldots \ldots \ldots$ & \\
\hline Methyl bromide .......... & 9 & 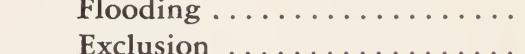 & $\begin{array}{l}35 \\
25\end{array}$ \\
\hline General precautions with poisons. & 9 & ging natural enemies. & $\begin{array}{l}35 \\
36\end{array}$ \\
\hline Trapping, shooting, and exclusion & 10 & Encouraging nat & 36 \\
\hline Encouragement of natural enemies & 10 & Moles & \\
\hline ods of control. . & 10 & 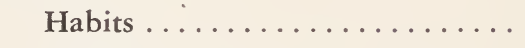 & 37 \\
\hline California ground squi & 1 & Methods of control ............ & \\
\hline Habits & 11 & $\ldots \ldots \ldots \ldots \ldots$ & 38 \\
\hline$\ldots \ldots \ldots$ & 1 & d gases ..... & 9 \\
\hline its ........... & $\begin{array}{l}13 \\
13\end{array}$ & its................ & 9 \\
\hline d hibernation.... & 14 & Meadow mice... & \\
\hline$\ldots \ldots \ldots \ldots \ldots$ & 15 & Kangaroo rats .. & 43 \\
\hline Methods of con & 15 & Muskrats....... & 43 \\
\hline barley ....... & 15 & Rabbits ....... & 45 \\
\hline ait.......... & 17 & Black-tailed jack rabbits... . . . . . & 45 \\
\hline on disulfide. . & $\begin{array}{l}18 \\
20\end{array}$ & Snowshoe rabbits .......... & 46 \\
\hline s...... & 20 & Cottontail and brush rabbits..... & 46 \\
\hline$e \ldots \ldots \ldots$ & 21 & Rabbit control $\ldots \ldots \ldots \ldots$ & 47 \\
\hline hous gases ....... & 21 & $\ldots \ldots \ldots \ldots$ & 47 \\
\hline$\ldots \ldots \ldots \ldots \ldots$ & 21 & $n g \ldots \ldots \ldots \ldots \ldots$ & 48 \\
\hline$\ldots \ldots \ldots \ldots \ldots$ & 21 & Repellents ........... & 48 \\
\hline$s \ldots \ldots \ldots$ & 22 & Trapping $\ldots \ldots \ldots \ldots \ldots$ & 48 \\
\hline Other me & 22 & Poisoning $\ldots \ldots \ldots \ldots \ldots$ & 49 \\
\hline Costs of control & 23 & Encouraging natural enemies.. & 49 \\
\hline Dther ground squirrels. & 23 & Literature cited & 50 \\
\hline
\end{tabular}




\title{
CONTROL OF FIELD RODENTS IN CALIFORNIA
}

\author{
TRACY I. STORER ${ }^{2}$
}

\section{WHY CONTROL RODENTS?}

FIELD RODENTs, the ground squirrels, tree squirrels, pocket gophers, field mice, kangaroo rats, muskrats, and rabbits, are all seeking their needs for successful existence-to obtain enough food, to find adequate shelter, and to escape their enemies. Whenever man's farms and gar-

Field rodents do extensive damage to agriculture in California and some of them carry diseases such as plague, tularemia, Rocky Mountain spotted fever, and relapsing fever. dens offer food or shelter for rodents, they will become his competitors. They affect his business, pleasure, and health.

The losses caused by rodents are difficult to estimate. Earlier it was guessed that damage by ground squirrels amounted to between 5 and 12 million dollars annually, and that by pocket gophers perhaps 8 million dollars. Where there is no control, ground squirrels may cause losses to cereal crops amounting to from 10 to 15 per cent or more. They materially reduce the forage in pastures. Pocket gophers may seriously injure or kill individual orchard trees and can be an expensive nuisance in alfalfa, truck crops, and home gardens. Ground squirrels, pocket gophers, and muskrats may damage ditchbanks and levees by burrowing. Jack rabbits and, less often, cottontails may gnaw bark on trees and vines and thus decrease production or even kill the plants. Rabbits may seriously reduce the production of truck and field crops and home gardens. The control measures carried out by farmers and gardeners on their own lands and by government officials on public lands serve to reduce the total damage.

Furthermore, these animals are carriers of some of the most serious diseases that may be transmitted to man. Plague was first detected in California in 1900 among rats in San Francisco. From rats it spread to the California ground squirrel and other rodents, and by 1946, plague had been demonstrated at one time or another in 35 counties. In humans the disease is called bubonic plague. In rodents it is called sylvatic plague. It is transmitted chiefly by fleas. Rats and ground squirrels are the animals most often affected, but it sometimes occurs in other rodents. When it is transmitted to man from squirrels it may take on a more deadly form known as pneumonic plague. This form may be transmitted directly from one person to another by coughing (droplet infection). Two small epidemics of pneumonic plague have occurred in California, with a mortality of more than 90 per cent.

A native disease, tularemia, was first discovered in the California ground squirrel. It occurs also in rabbits and, less often, among other rodents in many

${ }^{1}$ This publication replaces the section on field rodents in Extension Circular 79, Control of Injurious Rodents in California, which will not be published again.

${ }^{2}$ Professor of Zoölogy and Zoölogist in the Agricultural Experiment Station. 
parts of California and elsewhere. Man may contract the disease while skinning infected animals or, rarely, by eating improperly cooked rabbit flesh. The disease is also transmitted by several insects, notably deer flies (for which reason it is called "deer-fly fever"), and by ticks. The reservoir for tularemia, however, is in wild rodents.

Rocky Mountain spotted fever is a serious and often fatal tick-borne disease present in Lassen, Modoc, and eastern Siskiyou counties, and in other parts of the arid western interior. It is transmitted to man by the bite of infected ticks inhabiting various mammals, including rabbits.

Another disease, relapsing fever, is present around Lake Tahoe, Big Bear Lake in the San Bernardino Mountains, and other mountain regions. Carried by small chipmunks, it may be transmitted to man by the bite of certain ticks. A number of cases have occurred among humans in recent years.

\section{Because squirrels and other rodents may be carriers of disease, handling them or capturing them as pets should be avoided.}

General information on rodents as carriers of disease may be found in Hull (1941); $;^{3}$ details about rodent-borne diseases in California are given in Biennial Reports, California State Department of Public Health; and also in the Public Health Reports and the Annual Report of the Surgeon General, U. S. Public Health Service.

Several government agencies aid in control of field rodents. The U. S. Fish and Wildlife Service supervises rodent control on federally owned lands and, together with the California Department of Agriculture, advises and helps to direct operations in the counties. The U. S. Public Health Service studies rodent-borne diseases and conducts campaigns against rodents in and about seaports. The California Department of Public Health makes surveys of rodents to determine the presence of diseases that may be transmitted to human beings. When infections are found, reports are sent to the State Department of Agriculture. That agency then carries on control operations where necessary. The county agricultural commissioners are responsible for rodent control operations in the counties. But except where special danger to public health is concerned, the responsibility for rodent control on privately owned lands rests with the individual.

Rodent control in California, public and private, has cost fully one million dollars annually in some recent years, and several million acres have been treated.

A few of California's native rodents are actually beneficial, and many are neutral so far as man's interests are concerned. Some, such as muskrats and cottontail rabbits, are useful as fur bearers or game animals to trappers or sportsmen, but can be harmful to the farmer. Certain rodents, in places, are believed to benefit the soil by "cultivation," and in other ways.

\section{HOW TO CONTROL RODENTS}

There is no one easy way to control all kinds of rodents, but certain methods that have been tested by repeated use will keep most species in check.

To decide what control measures to use, one must first know what rodent

\footnotetext{
${ }^{3}$ Sce "Literature Cited" at the end of this circular for titles of the books and papers which are referred to in the text by author and year of publication.
} 
is causing the trouble. Knowledge of the habits and especially of the food preferences, seasonal or year round, of each kind of rodent is essential for successful control. Brief descriptions of the habits of the principal injurious field rodents are given in this circular, but anyone who attempts to control rodents must study the animals in his area and check upon the results of each effort at control. The seasons when rodents breed and hibernate will determine when control measures will do the most and the least good. With burrowing rodents, the type and extent of the burrows will indicate whether poisonous gases are practical or how and where to place traps or poison baits. To aid in choosing and applying control measures, later sections describe important field rodents and some of their habits.

The general methods of control are briefly described in this section. Some important precautions are also given. More detailed directions will be found in the sections on particular rodents. There are six general means of control: (1) poison baits, (2) poisonous gases, (3) trapping, (4) shooting, (5) exclusion, and (6) encouragement of natural enemies.

\section{Poison Baits}

One of the commonest means of control is by poison baits. Food that the rodent likes-grains, greens, pieces of vegetables or fruits-is poisoned and scattered broadcast or placed in burrows or other protected spots. Baits should not be

Poison baits give good results with many rodents, but must be applied so as not to endanger human beings, livestock, and harmless wild life. scattered on the ground if there would be danger to livestock, beneficial wild life, or human beings.

Control work with poison, even under official agencies, has been criticized because it may kill other animals besides rodents. Hardly any control operation (except selective shooting) is without some possible danger to other forms of wild life. But careful use of the more conservative methods will keep this danger low.

The county agricultural commissioners prepare and sell certain kinds of poison bait, and sometimes have clean oat groats for making ground-squirrel bait. Several counties have one or more special rodent inspectors to direct control measures or actually apply them. In the past some counties have paid for materials and even for labor in poisoning rodents by baits and gas. But in most counties at the present time the landowner or tenant pays for materials and either provides or pays for the labor.

If the county agricultural commissioner cannot supply the bait needed, he can give the names of good commercial brands. Or the baits can be mixed at home, particularly if large quantities are needed. Formulas are given on later pages.

Both the poison and the bait should be adapted to the kind of rodent to be controlled.

Strychnine is the chief poison used for ground squirrels, pocket gophers, jack rabbits, and some lesser rodents.

Zinc phosphide has proved useful in controlling ground squirrels and meadow mice. 
Phosphorus has been used to some extent for ground squirrels, as has arsenic. Phosphorus and arsenic are less satisfactory, however, and involve greater hazards to other animals and to human beings; their use is not recommended for routine control by private individuals.

Commercial preparations of various types are sold for rodent control. Besides the poisons mentioned here, such as strychnine and zinc phosphide, there are compounded poisons or prepared baits sold under brand or trade-marked names. Some are satisfactory; some are too dangerous for private use; and many are of little value. Any poison or poisoned bait to be offered for sale in California must first be tested by the State Department of Agriculture. Only those which are satisfactory are licensed for sale in California. The name and the percentages of the active ingredients, with proper warnings concerning the poison used, must be printed on the label. Some companies and storekeepers make up approved "government" ground-squirrel poison and other formulas; for small applications such preparations are economical.

Certain other poisons have proved useful under special conditions, but either are not suited to field rodents or are too dangerous for use by untrained operators.

Antu (alpha-naphthylthiourea), a new material, is useful for Norway rats but is not sufficiently poisonous to other rodents for use in control.

Two other rodent poisons are not available for use by the general public because of the relatively greater hazards they involve. Baits poisoned with these chemicals bear no indication of their poisonous nature in appearance, taste, or odor. Both are poisonous to rodents, other wild animals, domestic livestock, and man. These are thallium sulfate and "1080."

Thallium sulfate (thallous sulfate, $\mathrm{Tl}_{2} \mathrm{SO}_{4}$ ), a "heavy metal" poison obtained from smelters, has been used by government agencies for controlling both rats and field rodents. Thallium-poisoned grain several times came into the hands of private individuals who innocently used the grain for human food. As a result, several persons became ill, and some died. Sale or possession of thallium for rodent control in California is restricted by law to federal, state, county, and municipal officers and employees (California Agricultural Code, 1943, Sec. 1066.5). Statements that continued use of thallium-coated grain would lead to the sterilization of lands for plant growth, have proved to be unwarranted. (See Crafts, 1936; and Horn, et al., 1936.)

"1080" (sodium fluoroacetate), a wartime discovery, has been used since 1945 by military and government agencies for rodent control. It is as poisonous for all kinds of animals as any other material used. Wherever it is used, there is great danger that dogs and cats may eat rodents killed by "1080" and be poisoned. This material, therefore, should be employed only by properly trained persons and only in certain kinds of places.

There is no certain antidote for either of these poisons. Thallium is a slowacting poison, but "1080" works so rapidly that it has been impossible to save experimental animals even with prompt attention and under the best laboratory conditions.

\section{Poisonous Gases}

Several poisonous gases have been used for controlling ground squirrels and, less often, gophers. Of these, the most generally used is carbon disulfide. The 
method of application varies with the gas. These gases can be bought in cans or drums from dealers in garden supplies.

Carbon disulfide and other poisonous gases are used to kill rodents in their burrows. All these gases are dangerous poisons and some are explosive.
Sulfur dioxide has been widely used in the past for killing ground squirrels, and is still sometimes used. Special machines (see page 19) are needed to produce the gas by burning sulfur and to force the vapor into the burrows.

Carbon disulfide, although inflammable and explosive, is now used in large quantities for rodent control in California. It may be pumped into the burrows, or waste balls may be soaked in fluid carbon disulfide and thrown into the burrows.

Hydrocyanic acid gas was tried for squirrel control but did not prove satisfactory in California. This gas is used, with good results, for rat control. It is generated in the burrow by placing calcium cyanide in flake or dust form in the burrows.

Methyl bromide is a relatively new fumigant, first employed against insects; since 1936 it has been used by the State Department of Agriculture for followup operations against ground squirrels (see Berry, 1938). Since this gas kills fleas and other insects in the burrows, it has a decided advantage in plaguecontrol work. It is very poisonous, and at least one human death has occurred through its improper use in insect control. Special applicators are necessary to distribute the gas, and it costs too much (3 cents or more per burrow) for routine work. It is purchased as a fluid under pressure in heavy steel cylinders or in 1-pound cans.

\section{General Precautions with Poisons}

The following precautions should never be forgotten:

1. Label the containers for poison and poisoned baits "POISON."

2. Keep all such containers locked up out of the reach of children, irresponsible adults, pets, and livestock.

All of the substances used for poisoning field rodents are dangerous to human beings and to domestic animals. They should therefore be handled, stored, and labeled with great care.
3. Store carbon disulfide in tightly stoppered cans or drums in a cool dry place, out of doors, or in a separate building, away from all fire, matches, and sparks. It is a dangerous explosive.

4. Mix poison baits, particularly zinc phosphide baits, out of doors or in a wellventilated building where there will be less hazard to the operator.

5 . Do not breathe the dust when sifting dry strychnine or other dry poison over baits.

6. Wear gloves when mixing or distributing poison baits, particularly if they contain zinc phosphide.

7. Wash hands carefully after mixing or handling baits, even though gloves have been worn.

8. Wash utensils after mixing baits, and do not use them for any other purpose.

9. When using poison gases, always handle the materials out of doors; do 
not breathe the fumes; stand up-wind when using or placing the material in burrows.

The minimum lethal dosage of strychnine for a human being is thought to be about 0.5 grain, or 35 milligrams. Thus about $25^{\circ}$ kernels of strychninecoated barley would be enough to kill a man. About 5 ounces of zinc phosphide bait may be lethal for a man. Carbon disulfide is lethal in a concentration of about 1 part in 1,000 parts of air with 30 minutes' exposure.

Antidotes for these poisons are uncertain in their action and are different for the various poisons mentioned. If accidental poisoning occurs, a physician should be called at once.

\section{Trapping, Shooting, and Exclusion}

Trapping is effective for control of pocket gophers and moles, mice in houses, and wood rats, and is often used for other species.

Shooting will control small numbers of ground squirrels and rabbits.

Exclusion, where practicable, is the best method because it may bring lasting results. It can be used to protect small plots or gardens against ground squirrels, pocket gophers, and rabbits. On a large scale it is expensive, and it cannot be applied to all species or situations.

\section{Encouragement of Natural Enemies}

All the common rodents originally had natural enemies that helped to check their increase. Many of these enemies have been reduced in numbers and some even eliminated by man, and yet they are an asset to agriculture. Some of them, such as coyotes, also prey on domestic animals and birds, and their economic value as checks on rodents has to be balanced against the harm they do. Certain natural enemies, however, such as the red-tailed hawk, the barn owl, and the gopher snake, are so useful that only a very shortsighted person would destroy them; yet many farmers kill every hawk and snake they see, without regard for its usefulness. Whenever possible, farmers should protect the owls, hawks, snakes, and other animals that prey on rodents.

\section{Undesirable Methods of Control}

There is a popular idea that certain rodents may be killed by disease germs (virus) spread on baits. Bacterial cultures have been sold for this purpose, but the State Department of Public Health has made such sale illegal in California. These cultures not only often fail to reduce the number of rodents, but also sometimes carry infection to man. When these baits are spread among a population of rodents, some of the exposed animals die, but a certain number always survive, become carriers of the infection, and sometimes, by their droppings, contaminate supplies of food intended for human use. The use of such bacteria (which belong to the paratyphoid group, Salmonella) to control rats about certain institutions has several times resulted in outbreaks of food poisoning among the human inmates. Efforts at control of rodents by spreading disease among them are impractical and dangerous to human beings.

Disease among wild rodents at times kills off numbers of the animals; but either too little is known about such diseases for them to be used profitably in rodent control, or else they are transmissible to man, and therefore dangerous. 


\section{CALIFORNIA GROUND SQUIRRELS}

The most important ground squirrels in this state are the large, long-tailed "digger," or California ground squirrel (Citellus beecheyi and its subspecies; fig. 1), that inhabits most of the state except the desert portions; the smaller, short-tailed Oregon ground squirrel $(\mathrm{C} i$ -

Ground squirrels are the best known and most injurious rodents in California; they destroy crops, damage irrigation structures, and carry disease. tellus oreganus; fig. 8 , p. 24), that lives in the northeastern plateau counties; and the golden-mantled ground squirrel (Callospermophilus chrysodeirus or Citellus lateralis) of the higher mountains. The latter two species are discussed in the next section (page 24). Several smaller species live in arid regions, both west and east of the Sierra Nevada, but usually are of minor economic importance. For detailed accounts of species see Grinnell and Dixon (1918), Howell (1938), and Linsdale (1946).

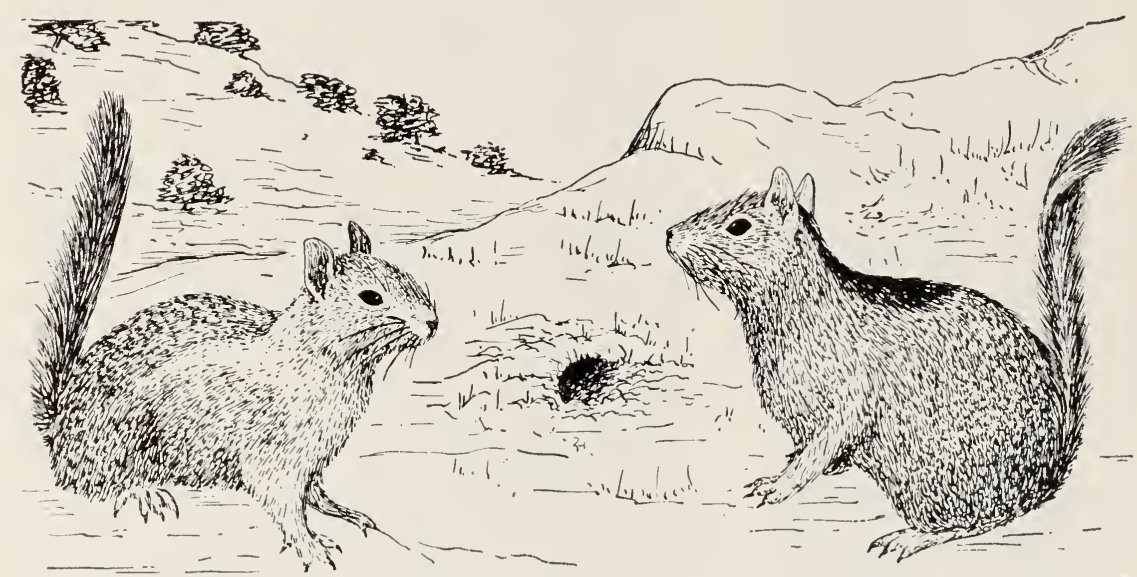

Fig. 1.-California ground squirrels. Beechey ground squirrel at the left, and Douglas ground squirrel at the right. Head-and-body length of these species is abcut $9^{1 / 2}$ to 11 inches and the tail 6 to 8 inches.

Seven varieties or subspecies of the California ground squirrel occur within the state, each in a separate area. The most widespread of these are (1) the dark-colored Douglas ground squirrel (Citellus beecheyi douglasii; fig. 1, right), with much black between the shoulders, which occurs northward from San Francisco Bay throughout the regions west and north of the Sacramento and Feather rivers; (2) the brownish Beechey ground squirrel (C. beecheyi beecheyi; fig. 1, left), which occupies coastal California from the Golden Gate and Carquinez Strait south nearly to San Diego; and (3) the gray-toned Fisher ground squirrel (C. beecheyi fisheri), which inhabits the greater part of central California from the Feather and Sacramento rivers south to the southern end of the San Joaquin Valley. Other varieties occur in the Owens Valley, Tahoe region, and extreme south.

These are the largest ground squirrels in California; the head and body are about $91 / 2$ to 11 inches long and the tail from 6 to 8 inches long. The differences 

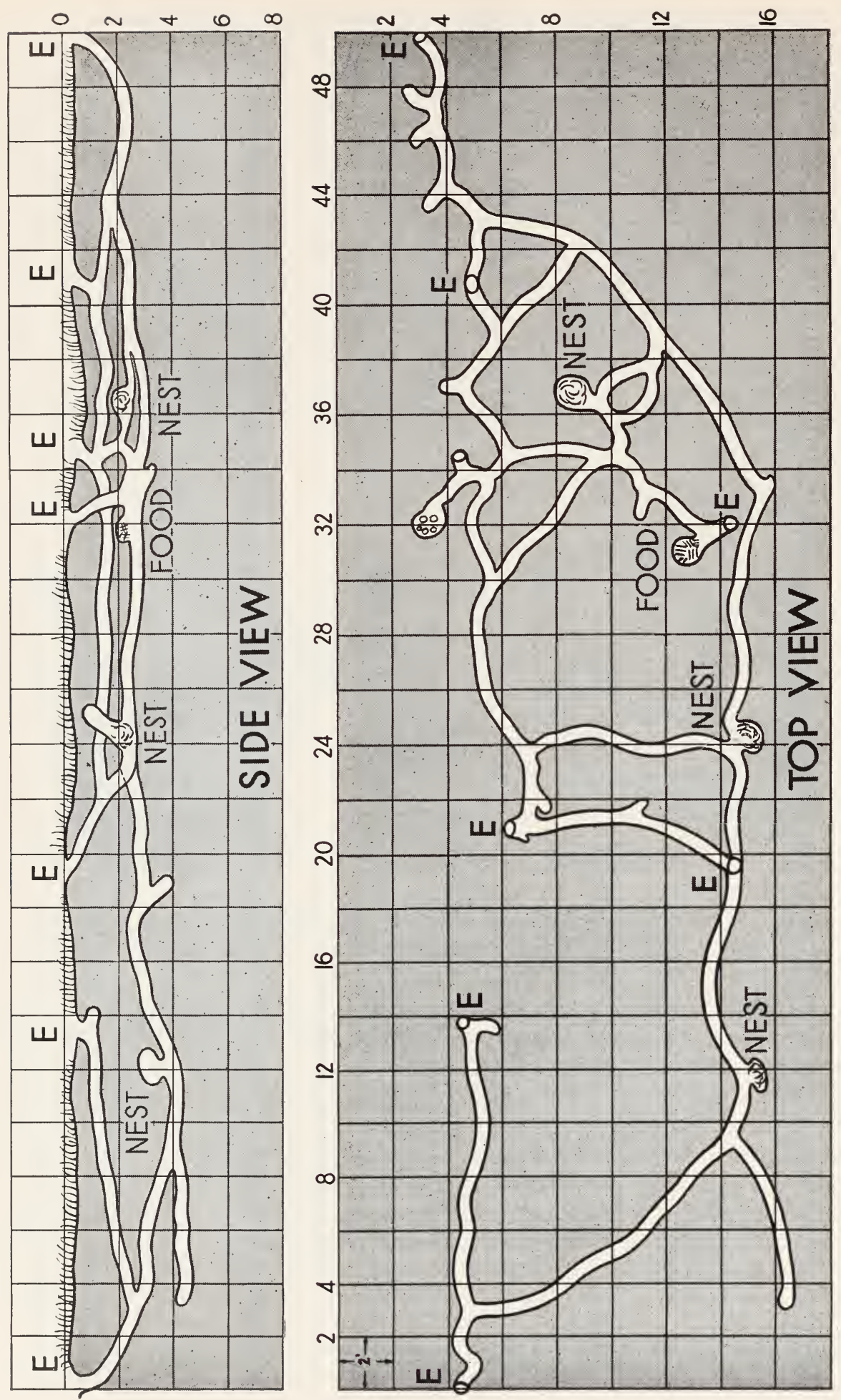

苂

ฮร

०ै

कำ

¿ॄ

$\ddot{ن}$

ป气

这

데. .0

एक

$\Xi 0$

ב

킁

항

플.

흘

తึ็

흐

40

E -

क

के

ㅊ.

뭄

כ)

$\div$

$\because$

8 ป

त

Ч

율

U్

כ

ॠ

$\frac{\pi}{2}$

i

is 
between the varieties are not important in economic relations, except that the Douglas ground squirrel seems to be somewhat easier to control.

Every ground squirrel has two thin, internal cheek pouches, opening just inside the lips, one on each side of the mouth, which are used to carry food. This characteristic is important in control because ground squirrels may be killed by absorbing poison on baits through the lining of the pouches, as will be discussed in a later section (p. 16).

\section{Habits}

Ground squirrels are ground-living; they find most of their food on the surface of flat country, hillsides, or embankments. Some kinds can climb trees, however, and may reduce yields from fruit or nut trees. Some live in open forest, scattered chaparral, or rock piles,

Knowledge of the habits of ground squirrels in burrowing, feeding, hibernating, and breeding, is important in choosing control methods and deciding when and how to apply them. but seldom in heavy growths of forest or brush. They are fair-weather animals, active by day in the warmer season of the year and on the warm days in winter.

Burrows. All species of ground squirrels dig burrows, which they use for safety retreats, for shelter during very hot or rainy weather and during hibernation, for occasional storage of food, and for the rearing of young. Burrows are made in flat lands, in hillsides or among rocks, and also in ditch, road, and railroad embankments. The entrances to squirrel burrows are always open.

The burrows (fig. 3) of California ground squirrels average about 4 inches in diameter, and individual burrows are 5 to 30 feet or more in length. Most tunnels are within $21 / 2$ to 4 feet of the ground surface, but at Davis one was found $61 / 2$ feet deep and in Fresno County one was dug into 28 feet below ground level in a chalk pit. It is important to know the approximate volume of burrows when gas is used for control. The estimated volume of certain representative burrows ranged from 1 to 18 cubic feet. Some are simple short tunnels, but others have many branches. Often there are two or more openings. Some are "colonial burrows" occupied by several squirrels. The most complicated system yet found had 33 openings, a total of 741 feet of tunnels, and a volume of about 100 cubic feet. It contained 6 females and 5 males.

Feeding Habits. During the rainy months, November to March or April, ground squirrels feed chiefly on green herbage. Seeds lying on the ground surface are hulled and eaten as found. Later, when the new seed crops begin to ripen, the squirrels gather seeds without hulling and put them in their cheek pouches, to carry off and hide in shallow caches excavated in the ground surface, or in crevices between rocks. Some are carried into the burrows for later use. Seeds of both wild and cultivated plants, particularly grains, are taken in quantity. In orchard districts these squirrels climb trees for almonds, walnuts, and the soft pits of growing peaches and apricots. Sometimes they may also forage in truck patches.

The feeding habits of ground squirrels cause greatest damage to grain and pasturage. In fields they dig up sprouting grain, and later pull down the ripen- 
ing heads. After harvest they may eat and carry off quantities of grain from shocks and stacks. On pasture lands they may take a good deal of grass and herbage that could otherwise be used by domestic stock. On open range, 200 California ground squirrels can eat as much green forage as 1 steer or 10 sheep. Both on isolated ranches and in well-developed areas, they often seriously deplete grain, nut, and fruit crops.

Estivation and Hibernation. All California ground squirrels living at high altitudes and some of the population, probably adults, at lower elevations hole up for a part of each year. Before this period of inactivity, the animals acquire a surplus of fat. After going below ground the squirrel plugs part of

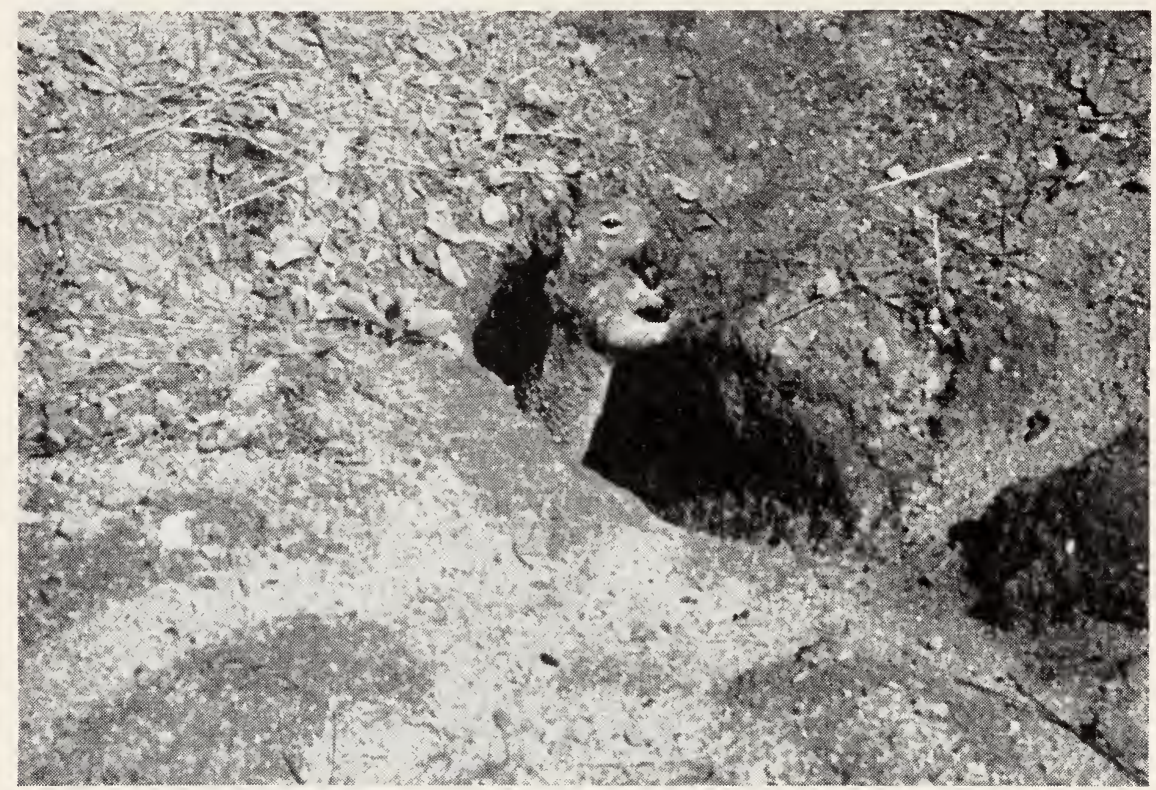

Fig. 3.-Beechey ground squirrel at entrance to well-used burrow: Courtesy of California Forest and Range Experiment Station.

the tunnel just above the nest with earth to as much as 3 feet in length and curls up in its nest below the tunnel plug. The burrow entrance remains open. While the squirrel is holed up, the rate of heart beat and respiration are greatly reduced, and the body temperature drops nearly to that of the burrow.

The time at which any one squirrel or those in a given locality hole up varies. In the lowlands some enter estivation early in summer, whereas in the high mountains others do not begin hibernation until late in autumn. Emergence occurs in late winter or early spring. Estivation ("summer sleep") begins as early as mid-May in the hills east of Livermore, and by late June in the hills of eastern Kern County, whereas it does not commence until early August in Siskiyou County.

This habit of estivation explains why old breeding adults suddenly appear in spring, after all squirrels active in a field during fall had been killed and there seemed no chance for migration from the surrounding fields.

The exact extent of estivation among our ground squirrels is unknown because it is very difficult to follow an individual squirrel through its activities 
for any length of time. Nevertheless, it is extremely important to carry on intensive control in the spring and early summer when all squirrels are active. During hot summer weather and in the fall and early winter, some of the squirrels may be underground and out of reach. And there is also some doubt whether dormant animals are fatally injured by fumigating their burrows with carbon disulfide.

Breeding. The California ground squirrel in central California breeds mainly during the first half of the year, but some young are produced later in the year. In the interior valleys, females carrying young are most numerous in February and March. In Los Angeles County regular breeding activity was found to have begun by December, and in March, 7o per cent of some 2,000 females examined there in 1925 were pregnant (Storer, 1930). The breeding season is somewhat later along the coast and in the mountains.

Ground squirrels probably produce only one litter a year. Of the average litter, possibly about 5 or 6 squirrels survive long enough to appear aboveground. Where squirrels had been far reduced by control for two or more years and food for those remaining was greater, an average litter of nearly 10 has been noted (Jacobsen, 1923).

The young grow rapidly and are seen in greatest numbers during May and June, when they may scatter out to new territory or move to unoccupied old burrows. Control operations, therefore, should be especially intensive in late winter and early spring.

The rate of reproduction in ground squirrels is such that unless go per cent are eliminated in a given year there will be no general reduction in numbers. Theoretically, it would require eight to nine years of control at this rate to rid a given piece of land of squirrels entirely. And this would occur only if there were no reinvasion by migration from adjacent areas. Squirrels have been known to migrate from 1 to 5 miles into new areas. These facts show that persistent and intensive work is needed to keep down the squirrel population. Furthermore, coöperative efforts by all farmers in a region are essential; otherwise cleared areas will be invaded by squirrels from lands where control is not practiced or is ineffective.

\section{Methods of Control}

Various baits and several kinds of poison have been used for squirrel control. Whole barley and strychnine alkaloid (formula 1) have been most widely used by private landowners. In recent years, zinc phosphide (see page 17) on potted barley (hull removed by milling) or on

For ground squirrels the most important control methods are poison baits and poisonous gases. Natural enemies should be protected. Trapping, shooting, and other methods are useful in special situations. oat groats has been used.

Strychnine-coated barley is used in that part of the dry season when the squirrels are "pouching"-that is, gathering seeds and grain in their cheek pouches to store or to carry to some favorite eating place. The barley is coated with the less soluble strychnine alkaloid, together with substances thought to disguise the taste. Kernels are picked up by the squirrels and placed in their pouches. There the strychnine coating is absorbed through 
the delicate lining of the pouches, killing the animals. At other times of year, the squirrels take scattered seeds as found, eating each kernel after quickly removing the hull, and the strychnine coating usually does not have a chance to affect them. Sometimes squirrels will refuse to take strychnine-coated grain. Where grain or other crops are maturing, the animals may turn to these and avoid poisoned bait.

The exact time to use strychnine grain for best results must be determined by the person doing control work. It will vary according to locality and year. The activities of the squirrels should be observed. Prebaiting part of an area with unpoisoned grain is a simple test which should first be made to determine whether the squirrels will take and "pouch" the bait used.

FORMULA 1

\section{Strychnine-coated Whole Barley for California Ground Squirrel (Government Formula)}

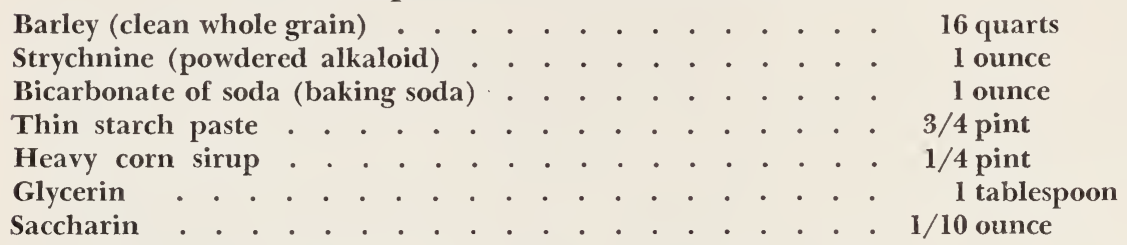

Mix the strychnine, baking soda, and saccharin together dry. Prepare the starch paste by stirring 1 heaping tablespoon of dry gloss starch in a little cold water until smooth, pour into $3 / 4$ pint of hot water, boil and stir until clear. Add the dry strychnine, soda, and saccharin, then the con sirup and glycerin; stir thoroughly. Pour the hot mixture over the grain, turning and stirring until each kernel is coated. Spread the coated grain out in a thin layer until the coating is thoroughly dried. Then store in a can or sack, properly labeled as POISON, until used.

The poisoned grain should be scattered by hand or with a spoon on hard bare ground, or along or near the cleared surface of squirrel runways. It is less likely to be found and eaten if dropped in tall grass or on the soft earth about burrows. About 1 tablespoon should be scattered at each spot to cover 1 to 2 square feet; one quart provides 30 to 35 baits.

In farmyards or pastures or wherever there is livestock, the poisoned grain must be placed inside the squirrel burrows. In hot weather, bait in burrows is reported to give better results than if exposed on the surface.

Failures in squirrel control will follow the use of strychnine barley when rain washes off the poison coating or when squirrels refuse such bait. Failure may also result when squirrels are feeding heavily on filaree. It is believed that the high tannin content of filaree will counteract the effect of strychnine. This viewpoint has been questioned by Burnett (1932), whose experiments with Wyoming ground squirrels led him to believe that some individual animals could build up a tolerance to the poison by repeated doses in amounts that were not sufficient to kill. There are no studies of this kind on the California ground squirrel, but ordinarily about 20 kernels are considered enough to kill the average of this species.

Strychnine readily kills various wild rodents and birds, and, if taken in sufficient amount, can kill livestock. Quail, pheasants, and domestic poultry can withstand relatively large doses of strychnine. They often refuse strych- 
nine-poisoned baits-but this is no excuse for carelessness in placing poisoned grain. Strychnine-coated barley, even in small amounts, is poisonous to man, and therefore supplies of it should be locked up out of reach of children or irresponsible adults.

Zinc Phosphide Bait. Zinc phosphide is a dark gray powder with a slight smell of phosphorus. It is used on cereal baits with a "spreader" of mineral oil, petroleum jelly (vaseline), or lecithin oil (formulas 2 and 3 ), which holds the poison to the bait and helps to protect against rapid deterioration in the presence of moisture. In damp places the zinc phosphide slowly produces phosphine $\left(\mathrm{PH}_{3}\right)$, a poisonous gas. Zinc phosphide baits should be prepared and handled out of doors or in a well-ventilated building. Operators should wear gloves when mixing or distributing baits.

The principal baits used with this poison are whole barley, whole oats, and oat groats (oats with kernels flattened and without hulls). Whenever possible, it is best to purchase the prepared zinc phosphide baits from county agricultural commissioners, who also sometimes have clean oat groats for use in preparing baits.

\section{FORMULA 2}

\section{Oat Groats with Zinc Phosphide for California Ground Squirrel}

Oat groats (hull removed), lightly rolled . . . . . . . 100 pounds

Zinc phosphide, powdered . . . . . . . . . . . . 7 to 10 ounces

Petrolatum, or petroleum jelly (vaseline), melted . . . 16 to 24 fluid ounces

Mixing is best done in a steel drum containing baffle plates and mounted at an angle. Turned by a crank, this device tumbles and mixes the materials well. The oats and poison should first be mixed dry until the kernels are evenly coated with the blackish zinc phosphide powder. Then the melted petrolatum is added, and the drum turned again 30 to 50 revolutions. Mixing and handling the poisoned grain should be done out of doors. Workers should wear gloves and should avoid breathing gas fumes from the poisoned material. The grain may also be prepared in a cement mixer heated with a weed torch.

FORMULA 3

Whole Barley with Zinc Phosphide for California Ground Squirrel

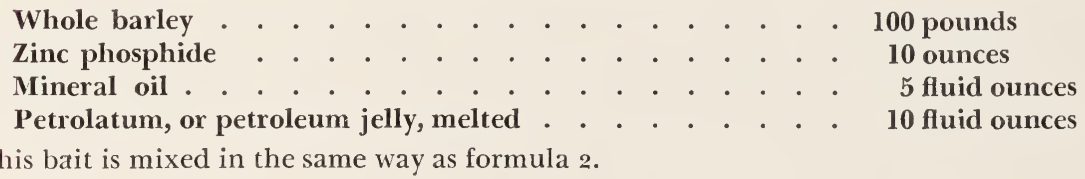

Zinc phosphide baits act directly when the squirrels eat or hull the poisoned grain. They do not need to be stored in the cheek pouches to poison the animals. They may be used in spring and even in winter-over a longer season than strychnine baits. Zinc phosphide is most effective when seeds of grain and of range grasses are scarce. When such seed supplies are easily available, the results of poison distribution may be irregular or poor. One pound of prepared grain provides about $5^{\circ}$ baits, which are placed in the same manner as strychnine-coated grain. Zinc phosphide baits may sometimes endanger livestock and game. Dogs have been killed by eating squirrels poisoned by zinc phosphide. 
Gassing with Carbon Disulfide. Ground squirrels and some other rodents can be controlled with poisonous gases. Gases will also kill other animals living in squirrel burrows, such as skunks, cottontails, burrowing owls, and snakes. The chemicals which have been used include carbon disulfide $\left(\mathrm{CS}_{2}\right.$; often called “carbon"), carbon monoxide $(\mathrm{CO})$, sulfur dioxide $\left(\mathrm{SO}_{2}\right)$, methyl bromide $\left(\mathrm{CH}_{3} \mathrm{Br}\right)$, hydrocyanic acid $(\mathrm{HCN})$, chloropicrin $\left(\mathrm{CCl}_{3} \mathrm{NO}_{2}\right)$, and tetra. chloroethane $\left(\mathrm{C}_{2} \mathrm{H}_{2} \mathrm{Cl}_{4}\right)$.

Carbon disulfide is the gas most widely used for ground-squirrel control. This liquid chemical takes fire and burns readily; it evaporates easily and

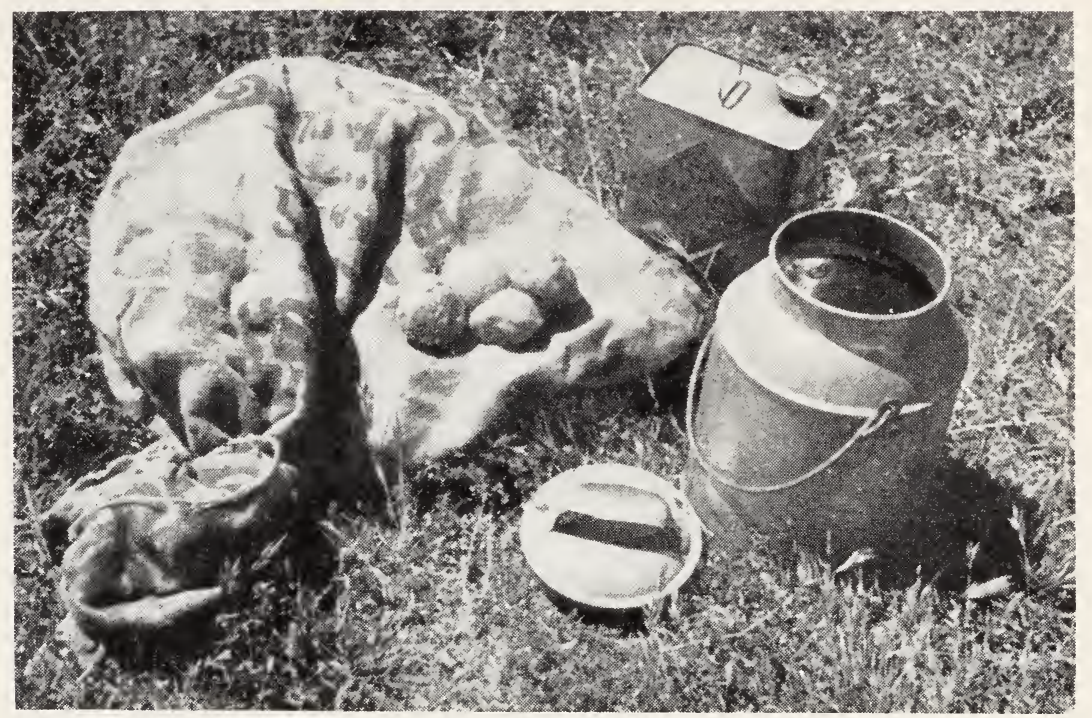

Fig. 4.-Equipment for using carbon disulfide on waste balls in ground-squirrel control: stock can of carbon disulfide, waste balls of jute, and milk can with tightfitting cover in which the waste balls are soaked in the fluid before being placed in the burrow. A stiff wire (not shown) hooked at one end forms a convenient means of lifting out waste balls and placing them in the burrows.

quickly; and, in the vapor or gas state, it is highly explosive. Stocks of carbon disulfide should be tightly stoppered to prevent loss and should be stored out of doors in a cool, shady place free from fire, sparks, or exposed lights. The fluid corrodes tin cans readily. Carbon disulfide is poisonous to man and to most animals, but it does not readily kill fleas.

Since it is heavier than air, carbon disulfide will settle in the lowest parts of an underground burrow, and will not pass higher than the burrow mouth unless forced up with a pump. The fluid vaporizes and spreads more rapidly at high air temperatures, but when put into burrows during the warm dry season much gas may be lost through surface cracks in the ground.

Carbon disulfide is applied in two ways: with a special pump to force the fluid or gas into a burrow, or by soaking waste balls in the fluid and then placing them in the burrow. Formerly the gas was ignited a few seconds after the disulfide was pumped into the burrow, but this practice has been given up, for the most part, because it takes longer and is a fire hazard. When condi- 
tions permit firing the gas, however, somewhat better control seems to result. Ten or 15 seconds after introducing the gas, a bit of paper or a small kerosenesoaked rag on the end of a stick or a stiff wire, 4 to 5 feet long, is lighted with a match and inserted into the open burrow. The operator stands at one side to avoid being burned by the explosion from the burrow mouth. Care should be taken not to set fire to near-by grass.

Waste balls about 2 inches in diameter, made of short frayed strands of jute (from grain sacks) are sold in sacks containing about 1,0oo balls. Wool trimmings or scraps of cloth also can be rolled up and tied to make waste balls.

The balls are soaked in fluid carbon disulfide (fig. 4), and one is thrown into each burrow. Each waste ball takes up about 2 fluid ounces; so, allowing for evaporation and spillage losses, 1 gallon of fluid will saturate $5^{0}$ to 60 balls. Before being put into the burrows, the waste balls should be drained for an instant as they are lifted out of the fluid. Immediately after a burrow is treated, the entrance should be closed with a shovelful of earth and quickly tramped down; or the entrance may be stuffed tightly with newspaper. Sometimes each waste ball is attached to a stiff wire about 3 feet long, which is used to push the ball well into the burrow and to withdraw it some days later for further use.

Several types of pump have been used to force carbon disulfide vapor into squirrel burrows. The Karbo-Killer, which was used for some years, treated 125 to 175 burrows per gallon, with 20 to $3^{0}$ strokes at each hole. Recently, the Demon Rodent Gun (fig. 5) has replaced most other

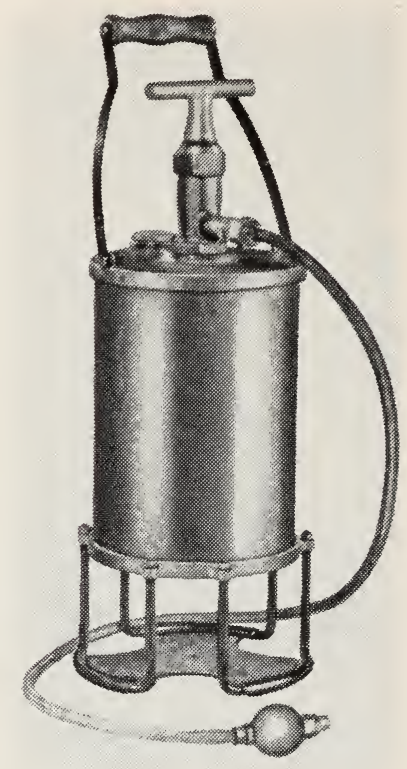

Fig. 5.-The Demon Rodent Gun for pumping carbon disulfide into rodent burrows. pumps. This machine consists of a metal cylinder containing fluid carbon disulfide. The central pump connects to a flexible hose ending in a spray nozzle. The nozzle is placed in the burrow, and the burrow mouth is plugged with a shovelful of earth or a wad of crumpled newspaper to prevent loss of gas. Then a stroke of the pump forces 1 fluid ounce of the fluid out and vaporizes much of it just inside the burrow. After the hose has been withdrawn, the burrow entrance is closed by trampling the earth or forcing in the newspaper. In later clean-up work, 2 fluid ounces of carbon disulfide is used per burrow. Some operators first go over an area and close all burrows by using mattocks or shovels, then apply the gas several days later to those that have been reopened by squirrels. Other consider that this method takes too much time except on clean-up work.

The Karbo-Killer and some of the earlier vapor pumps required numerous strokes, but forced carbon disulfide vapor more or less throughout the burrow; the Demon Rodent Gun requires only a single stroke, but tends to leave varying amounts of the liquid close to where the nozzle was inserted and does not force the vapor so far down the burrow. 
Sulfur Dioxide Gas. Sulfur is burned in the presence of air to generate sulfur dioxide. Various machines to produce and force this gas into squirrel burrows have been made and used by California farmers. One recent design uses a gasoline torch with a sulfur chamber in front of the flame; the draft created by the torch flame forces the fumes through a nozzle which is inserted in the burrow. Another type is a cylindrical tank through which air is forced by a handdriven rotary blower over the burning sulfur; fumes from the sulfur pass into a tapered nozzle or a large hose inserted in the squirrel burrow. The whitish fumes, besides killing squirrels below ground, will reveal leaks from cracks in

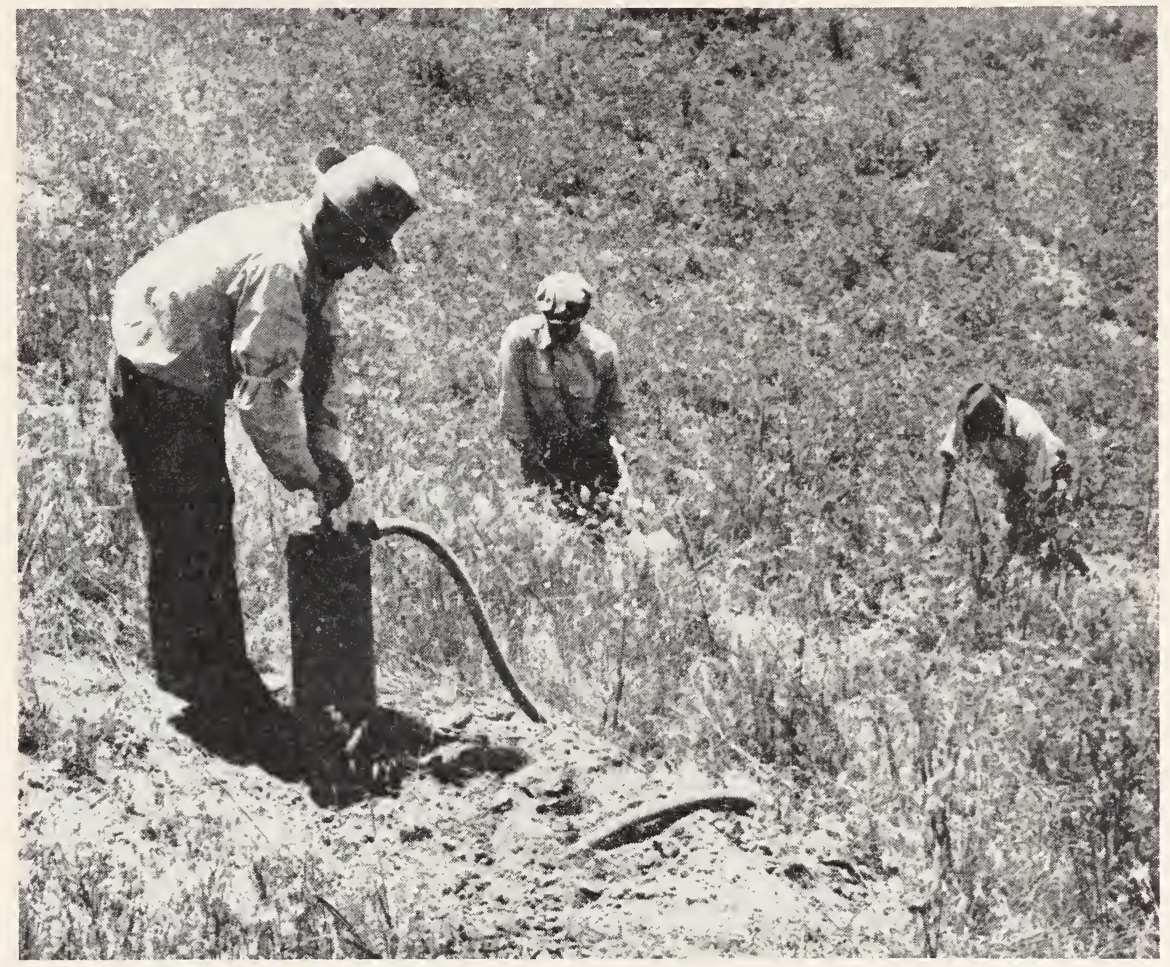

Fig. 6.-Use of the Karbo-Killer in ground-squirrel control. The hose is placed in the burrow and the entrance covered with earth (or plugged with crumpled newspaper). Carbon disulfide vapor is forced down the burrow by 20 to $3^{\circ}$ strokes of the pump and the hose is withdrawn. Men in the background are trying to find connecting burrows or cracks in the ground, all of which should be closed to retain the gas. Courtesy U.S. Soil Conservation Service.

the ground surface or from other entrances connected with the same tunnel system. Then the operator can shovel earth to close the leaks. Some users of sulfur dioxide report good results, but other operators are of the opinion that this gas is not effective enough.

Hydrocyanic Acid Gas. Calcium cyanide, in flake or dust form, placed in or pumped into a damp burrow, generates hydrocyanic acid (HCN), a deadly gas rapidly fatal to all forms of animal life. Between 1925 and 1930 , calcium cyanide was tried by official agencies for ground-squirrel control in California; but the results were not satisfactory. 
Methyl Bromide. Another gas fumigant is methyl bromide, used in recent years for clean-up operations on ground squirrels after other methods have been employed. It is supplied as a fluid under pressure in heavy steel cylinders or in 1-pound cans. It requires a special release valve and a trained operator to apply and is more expensive than some other gases.

Other Poisonous Gases. Tetrachloroethane is a new fumigant now being tried which can be applied by the same type of pump as that used for carbon disulfide at 1 to 2 ounces per burrow.

Carbon monoxide is contained in the exhaust gases of an automobile, and where field conditions permit driving to the sites of squirrel burrows, a hose from the exhaust pipe may be used to force the gas into the burrows, which should then be closed in. Running the engine for a few seconds forces the gas throughout the burrow. This method has been used under trees where carbon disulfide might damage or kill the trees.

Trapping. Traps may be used to remove small local populations of squirrels-as in dooryards or on ditchbanks-or to clean up those that escape poison or gas. This work may be done at any season. The wooden box-type gopher trap, with some changes (fig. 7), has proved useful in removing ground squirrels about residences and in certain places where other control methods are unsuitable (Becker, 1940). The back of the trap is replaced by a $1 / 2$-inch strap iron, half of the trigger loop is removed, and the bottom of the loop is straightened so that bait is held above the ground level; and the trigger holding the spring on top of the trap is changed to release when pulled forward toward the trap front. Entire walnuts, citrus fruits, and melon rinds proved effective baits in southern California. Several traps placed within a few feet of one another on top of the ground have completely eliminated small colonies of squirrels in a few days.

This type of trap has the following advantages over the spring steel trap: It can be baited, hence is more attractive to squirrels. It is more selective, catching fewer other animals. It kills the squirrel instantly, and it probably does not leave trap-wise squirrels, such as those which escape from steel traps.

The Young trap, a rectangular cage of hardware cloth with a drop door at either end and a central trigger pan in the floor, also has been used successfully for ground squirrels.

The steel jump trap (Oneida No. o or 1) was formerly used for groundsquirrel control. It lies flat against the ground and can be buried flush with the surface near a feeding place or in a burrow entrance. The trap should be anchored by a stake driven into the ground through the ring at the end of the trap chain; the stake also marks the trap's location. Bait such as barley may be scattered over the setting.

Squirrels taken in any of these traps should be handled with gloves to prevent fleas from getting on the operator. Squirrels taken alive may be killed by drowning while still in the traps.

Shooting. Small numbers of squirrels in fields or other open places may be destroyed with a long-range .22 caliber rifle. 
Natural Enemies. Ground squirrels have various natural enemies that aid in reducing the numbers of these rodents. Wherever it is practicable, these enemies should be protected and encouraged. They include the coyote, badger, weasel, wildcat, red-tailed hawk, golden eagle, rattlesnake, and gopher snake. Badgers, weasels, and snakes capture the squirrels in their burrows. Wildcats and coyotes lie in wait near the burrows until the squirrels come out in search of food. Coyotes and rattlesnakes may not be practical as aids in squirrel control, but the others named are often entirely beneficial.

Some observations in San Diego County give evidence of the service of hawks and golden eagles. Four nests (two golden eagle, one red-bellied hawk, and one red-tailed hawk) with young contained a total of 14 ground squirrels, 9 jack rabbits, and 2 pocket gophers. The dead rodents in the nests represented the surplus which the old birds had carried to their young, in addition to food eaten on the days of observation. Hawks and eagles may, therefore, kill more rodent prey than they and their young can eat.

The large predatory birds are important aids in rodent control; they work every day in the year and without expense to man. An occasional hawk may take chickens, but most of these birds are entirely beneficial.

Other Methods. Small isolated orchards of deciduous fruits or nuts may be protected from ground squirrels by smooth cylinders of tin fastened about the tree trunks. This tinning, if started about 2 feet above the ground and continued upward for 2 or 3 feet, will keep the ground squirrels out of the trees unless there are drooping branches on which they can climb.

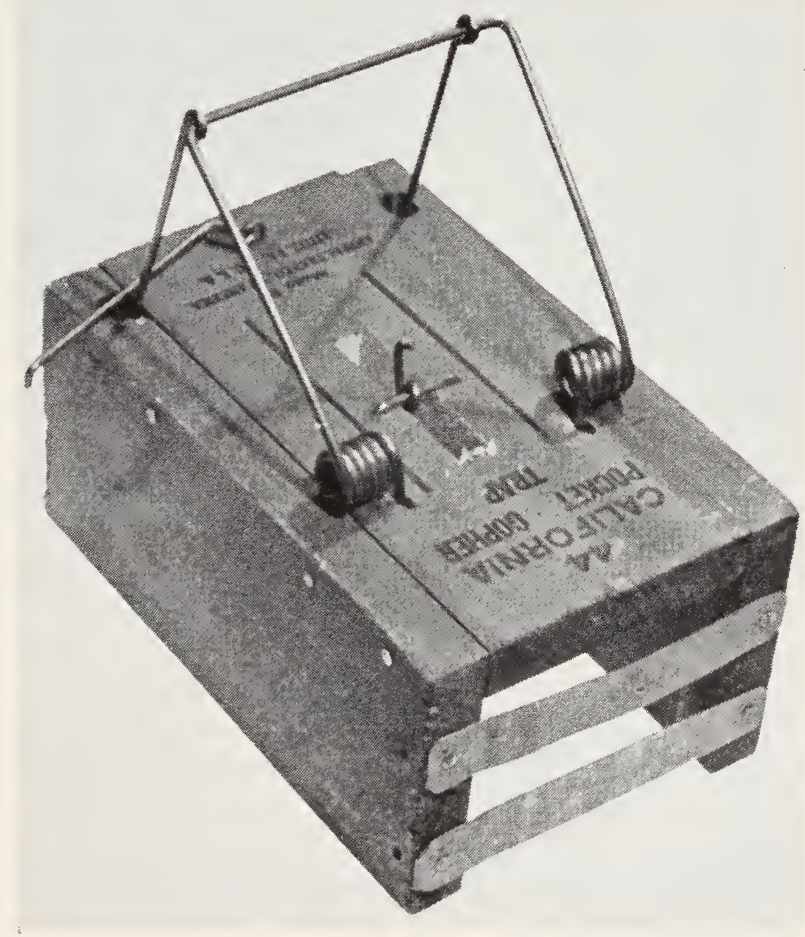

Fig.7.-Ground-squirrel trap (modified from wooden California pocket-gopher trap). Solid end replaced by 1 or 2 strap irons, inner end of trig. ger loop cut to form hook for bait, and trigger release on top of trap reversed (not reversed in photograph). 
Flat disks of sheet metal about 2 feet in diameter are often used to protect young roadside trees against defoliation by ground squirrels. A hole in the center of each shield admits the trunk of the tree, and a radial cut, from circumference to center, enables the shield to be placed in position, below the first branches.

Seed corn can be treated with coal tar to protect it from ground squirrels during germination (Lantz, 1917). For this purpose, 1 tablespoon of coal tar is added to a gallon of boiling water. When the mixture has cooled somewhat, the corn is stirred in and allowed to remain several minutes; germinating qualities will not be impaired.

\section{Costs of Control}

The amount of infestation, the method used, the current prices for labor, the speed and skill of laborers, and the kind of area treated all affect the cost of control. Large-scale operations on flat lands are less expensive per acre than those on small land units or in rough foothills with brush and rocks.

Some recent prices for materials were: alkaloid strychnine, per ounce, \$2.0o (1947); zinc phosphide, per pound, \$1.27 (1947); carbon disulfide, per gallon, 85 cents or higher $(1946)$; waste balls, per thousand, $\$ 3.00$ to $\$ 3.50$; and strychnine-coated grain, per pound, 4 to 10 cents (1942). Present-day variations in the cost of materials and in the cost and quality of labor make it impossible to give costs per acre. Some years ago, costs were as low as 10 cents per acre with poison grain and from 8 to 40 cents per acre with carbon disulfide.

\section{OTHER GROUND SQUIRRELS}

The Oregon ground squirrel (Citellus oreganus oreganus) inhabits most of Lassen, Modoc, and eastern Siskiyou counties. The related Belding ground squirrel (C. oreganus beldingi) lives in the high Sierra Nevada south to Fresno and Inyo counties. This squirrel is of

The Oregon and other ground squirrels in northern and mountainous parts of California may damage alfalfa, pasture, and grain. stocky build (fig. 8), with a short tail and plain brownish-gray coloration. The head and body are about $81 / 2$ inches long, and the tail is about $21 / 2$ inches. The animal is mainly an inhabitant of grasslands, and practically never climbs. It sits bolt upright when alerted, hence is often called "picket pin." The voice of this squirrel is a shrill trilling whistle that carries for a long distance.

The burrows resemble those of other ground squirrels but are smaller and not as deep in the ground. The food is chiefly grasses, pasture vegetation, and the leaves and stems of alfalfa and grain. Most Oregon ground squirrels hole up in July and emerge from hibernation by mid-March or earlier, even when there is still much snow on the ground. The average litter is about 8 , and the young appear from mid-May at the lower altitudes (3,ooo feet) until early June at higher levels.

The Oregon ground squirrel may be controlled by poisoned oats (formula 4) or poisoned dandelion greens. 
FORMULA 4

Poisoned Oats for Oregon Ground Squirrel

Oats, recleaned

Strychnine (powdered alkaloid)

Bicarbonate of soda (baking soda)

20 quarts

1 ounce

Heavy corn sirup. . . . . . . . . . . . . . . . . 1/4 pint

Glycerin . . . . . . . . . . . . . . . . . . . . . 1 tablespoon

Saccharin . . . . . . . . . . . . . . 1/10 ounce

Mix the strychnine, baking soda, and saccharin together dry. Prepare the starch paste by mixing 1 heaping tablespoon of dry gloss starch in a little cold water until smooth. Then pour into $3 / 4$ pint of hot water, boil and stir until clear. Add the dry strychnine, soda, and saccharin, then the corn sirup and glycerin; stir thoroughly. Pour the hot mixture over the oats, turning and stirring until each kernel is coated. Spread the coated grain out in a thin layer until the coating is thoroughly dried. Then store in a can or sack, properly labeled as POISON, until used.

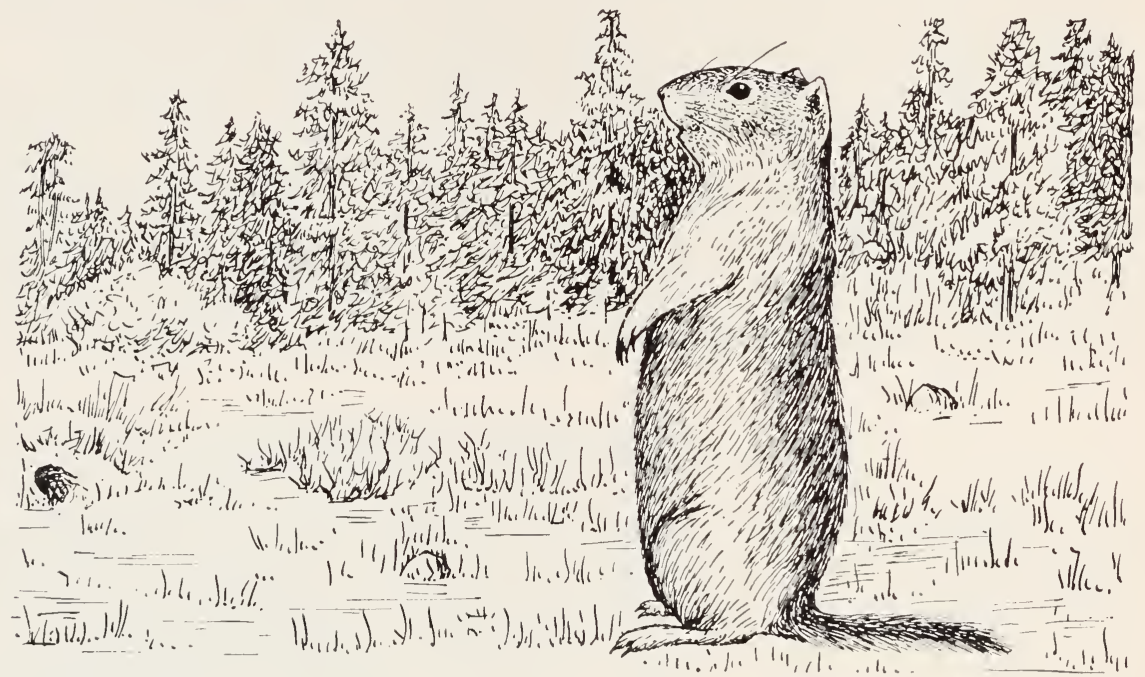

Fig. 8.-The Oregon ground squirrel of northeastern California. Head-and-body length is about $81 / 2$ inches, and the tail about $21 / 2$ inches.

The poisoned grain should be scattered by hand or with a spoon on hard bare ground, or along and near squirrel runways. It is less likely to be found and eaten if dropped in tall grass or on the soft earth about burrows. About 1 tablespoon should be scattered at each spot to cover 1 to 2 square feet; one quart provides 30 to 35 baits.

For poisoned dandelion greens, use formula 4 but substitute 5 gallons (bulk) of freshly cut green dandelion plants with roots, or fresh chicory, for the barley. Water cress or alfalfa leaves are less satisfactory. Two or three pieces of greens are put into each burrow; this does not endanger birds.

Carbon disulfide may be used to gas burrows of this squirrel in the manner described for the California ground squirrel.

Around mountain cabins and in some localities in eastern California and the deserts it sometimes becomes necessary to control other species of ground squirrels, and also chipmunks. In this group are the golden-mantled ground 
squirrel (Callospermophilus chrysodeirus), the antelope ground squirrel or chipmunk (Ammospermophilus leucurus), and the small striped chipmunks (Eutamias). The general methods described for control of the California ground squirrel (pages $15^{-23}$ ) are usually satisfactory. To rid a small areas of a few squirrels, as about a mountain cabin, the animals may be shot. Ordinary wooden rat traps can be used, but care must be taken when removing killed animals to prevent fleas or ticks, possibly disease-bearing, from getting on the operator. Gloves should be worn, and clothing should be treated immediately afterward with fly spray. Poisoned bait should be used only when it can be placed on the ground, under shelter of boards or logs, where birds or pets cannot reach it.

\section{TREE SQUIRRELS}

In the foothills and mountains of California there are two kinds of native treeinhabiting squirrels active during the daytime: the gray squirrel (Sciurus griseus) and the red squirrel (S. douglasii), also called chickaree or pine squirrel. The head and body of the gray squir-

The gray squirrel and the eastern fox squirrel sometimes raid fruit or nut trees. These animals are protected under the Fish and Game Code. rel measure about 10 to $111 / 2$ inches, with the tail nearly as long; the coat above is light steel gray in color, with the under surface of the body and margin of the tail white. The red squirrel is smaller, $71 / 2$ to $81 / 4$ inches, with the tail $4 \frac{1}{2}$ to $51 / 2$ inches long. Its coat is dark brown above with a reddish tinge on the back, and a black line along either side borders the white or buff belly. The tail is blackish with white-tipped margins.

The gray squirrel sometimes lives near nut and fruit trees and may raid these trees. One grower in Santa Cruz County reported that in years of short acorn crops the gray squirrels took many English walnuts and also gnawed into boxes of apples stored in the open. He captured several squirrels in box traps, transported them less than a mile from his ranch, and released them; no further damage was noted. Tin guards, like those described for ground squirrels, would exclude tree squirrels as well, provided there were no lowhanging branches on the trees and provided further that the trees were sufficiently far apart so that the gray squirrels could not travel overhead from tree to tree.

Tree squirrels have been completely protected for years under the California Fish and Game Code, but an open season was declared in 1946 for District 1 by the Fish and Game Commission. When damage by these squirrels occurs, a permit for control by shooting should be obtained from the local game warden.

A rusty-colored fox squirrel (Sciurus niger rufiventer) from the eastern states has been introduced and become established in several parts of California. It is grizzled brown above and rusty colored below, and is nearly the size of a gray squirrel. In the walnut orchards of the San Fernando Valley it is now sufficiently abundant to require annual control. Damage also is done to oranges and avocados, and lead-covered telephone cables are cut by the squirrels. Control is accomplished chicfly by use of wooden (gopher) traps as altered for taking ground squirrels (see page 22), and in places by shooting under permit. 


\section{POCKET GOPHERS}

Pocket gophers (genus Thomomys; fig. 9) are stout-bodied and short-legged, with blunt heads, conspicuous incisor teeth, and external, fur-lined cheek pouches for carrying food. They have brownish coats, small eyes and ears,

Pocket gophers are second only to ground squirrels in total damage to the agriculture of California. They are most troublesome in the areas that are intensively cultivated, and in the more fertile soils. Effective control will far reduce their numbers and the damage they do. short, nearly naked tails, and somewhat heavy claws on the front feet. The head and body usually measure 6 to 8 inches; the tail is 3 to 4 inches long.

Although pocket gophers and moles differ in both structure and mode of work, their workings are sometimes confused. The mole (fig. 16; pages 37-39) differs from the pocket gopher in the shape of the head, the color of the coat, and especially in having large front feet with stout claws. The illustrations (figs. 10, 11, and 17) show important differences between their methods of work and in the appearance of the tunnel openings and the earth piles around the tunnels. Differences between the surface workings of the two are described on pages $37-38$.

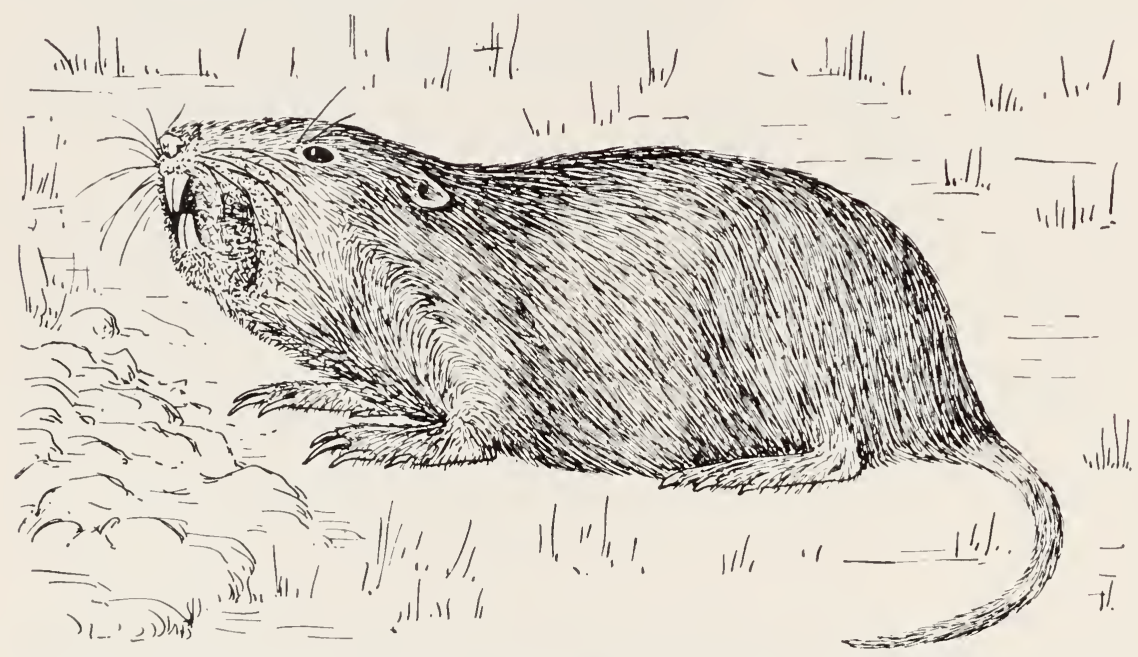

Fig. 9.-Pocket gopher. Distinctive features are the blunt head, prominent incisor teeth, fur-lined cheek pouches on either side of the mouth, slender claws on the forefeet, and scantily haired tail. The head-and-body length is about 6 to 8 inches, and the tail 3 to 4 inches. Compare with figure 16 .

Pocket gophers are distributed over almost all of California and inhabit practically all but very rocky soil; they are most abundant in the better soils. There are more than 40 species and varieties of these animals in California, but their habits and the methods for their control are essentially the same. The population of pocket gophers varies from place to place; large numbers may be present in alfalfa fields where no control has been practiced, while lands with sparse plant cover have few gophers. 


\section{Habits}

Burrows. The pocket gopher is strictly an inhabitant of the soil, living in burrows of its own construction, never climbing, and only seldom coming out on the surface of the ground. It digs clean-cut round tunnels, about 2 inches in

Gophers tunnel in the ground and eat the roots and crowns of plants. They damage alfalfa, truck crops, and garden vegetables and flowers, and sometimes girdle and kill trees and vines.

diameter. These are more or less parallel with the surface of the ground, usually at depths of from 6 to 14 inches, but deeper in places. The earth from these (figs. 10 to 12) is pushed out on the surface through short lateral tunnels made at frequent intervals (or pushed into abandoned tunnels). This results in a series of rounded surface mounds which, by their position, often give a clue to the location of the main tunnel. When putting earth out of a lateral tunnel, the gopher pushes the loads of earth into a more or less crescent-shaped pattern; and when the lateral is closed, a central depression in the mound usually indicates the location of the mouth of the lateral.

Fresh mounds are often dark because of the moisture in the earth that has been recently pushed out. Any grasses or herbs covered over by a mound are blanched (by loss of chlorophyll) after a few days, which provides another indication of its age. Trapping is most productive in fresh workings.

In addition to the lateral tunnels used to push out earth, the gopher makes short, almost vertical laterals in coming to feed on surface vegetation. These often are closed with earth that does not rise above the adjacent ground surface.

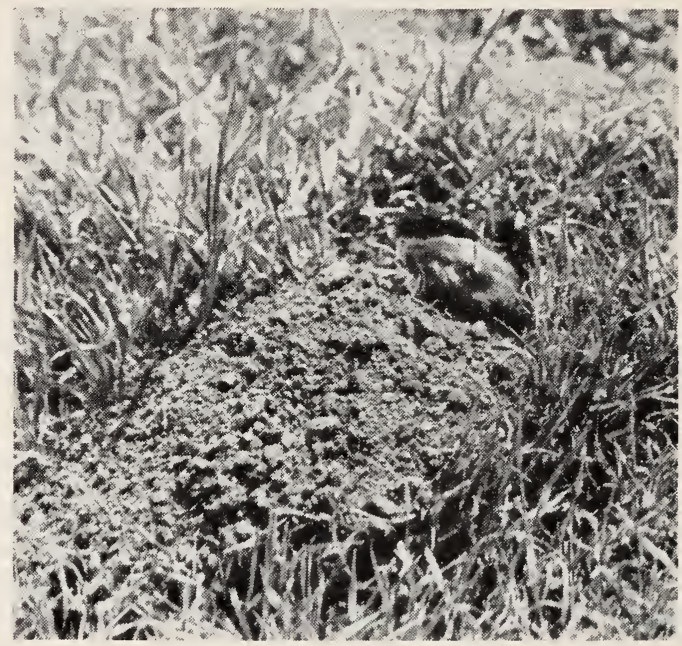

Fig. 10.-Live pocket gopher at the mouth of a lateral tunnel with a load of earth; previous loads have been pushed out at various angles so that the mound has a crescentic outline, the tunnel being at the center of the crescent. A feeding tunnel would have less earth around the entrance.

Gophers dig deeper tunnels in connection with their nests, and also dig short, steeply pitched "sumps," possibly to drain adjacent tunnels. The nest is usually in a chamber about 8 inches in diameter; it is constructed of fibers of grasses and other plants, shredded like fine excelsior. Food is often stored beside the nest or in other enlarged chambers off the tunnel system.

The burrow system of a pocket gopher may be many yards in length (fig. 12). Ordinarily each system is inhabited by a single gopher, although young may remain in the tunnel occupied by the mother for a time after leaving the nest. The systems of adjacent gophers may be connected, but connecting tunnels and even portions of the workings of a single animal are often plugged firmly 
with earth. When a gopher is trapped out of a tunnel system another animal may later move in and occupy that system. Moles or mice occasionally use gopher burrows. Pocket gophers are active throughout the year (even in mountain areas, where they work beneath the snow and put the surplus earth in tunnels in the snow), and fresh workings may be found in any month. Surface activity is less on dry areas during the hot summer months; at this season new mounds may be entirely lacking on unirrigated lands of the interior valleys. The animals are also less active during and just after a heavy rain.

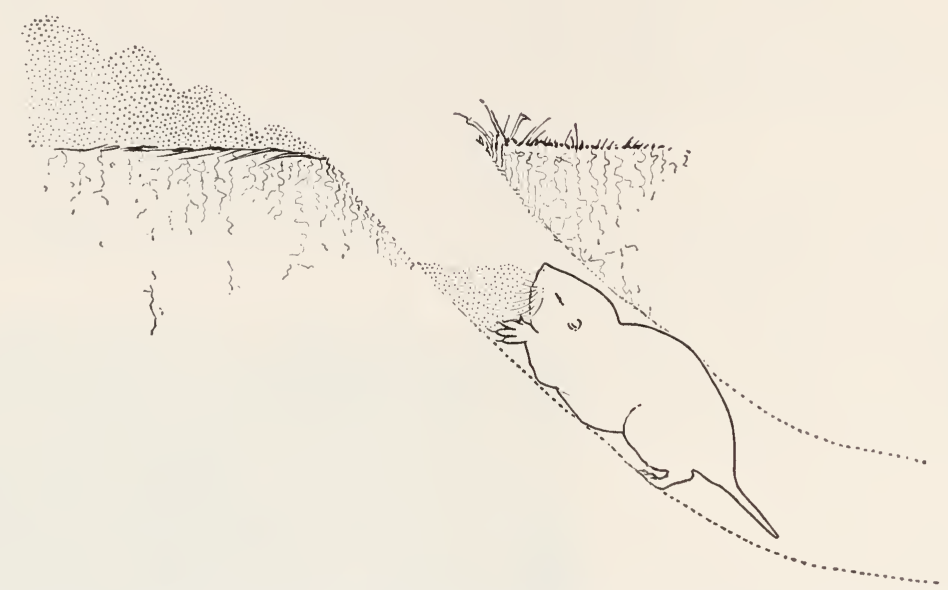

Fig. 11.-Method used by the pocket gopher in pushing earth out of the main tunnel through a lateral tunnel and onto the surface of the ground. The mouth of the lateral remains open while excavation is in progress; successive loads of earth are pushed in different directions from the mouth of the tunnel. Compare with figure 17 .

Breeding. On pasture lands and on uncultivated and unirrigated areas there is evidently a limited breeding season some time after the beginning of the rains, when green forage becomes available in quantity. On such areas there is probably a single annual brood. But in irrigated regions, especially in alfalfa fields where green forage is always available, breeding occurs throughout the year. In such places a female may bear more than one litter per season and up to 3 litters per year (Dixon, 1929; Miller, 1946). At altitudes of 5 , ooo feet and higher, breeding evidently occurs in June and July.

Investigations at Davis indicate that the average litter is between 5 and 6 , but may vary from 1 to 13 . About one third of adult females were found pregnant in April, none in September. The percentage of pregnancies increased with the size and age of the females (Miller, 1946).

The young remain in the nest for several weeks after birth, but eventually leave the parent tunnel system for an independent existence. They often wander some distance overland and start their small tunnels in new places. Adults also sometimes move overland. Gardens and fields earlier free from gophers thus may become tenanted by young in the spring or summer. The following dates indicate approximately when most of the young scatter out, although some appear both earlier and later: southern California, March 20; San Joaquin and Sacramento valleys, April 1; Owens Valley, April 15; foothills of the Sierra Nevada, April 30; northwest coast region, May 15 . 
Damage by Pocket Gophers. Gophers do immediate and specific damage to man's interests through their feeding habits and their tunneling. Production in alfalfa fields can be seriously reduced by their destruction of root crowns. Gophers damage truck plants by eating the roots. Valuable plants in flower gardens, especially those with bulbous roots, are often destroyed. Gophers cut roots of trees and vines and gnaw the bark of trees, at times completely girdling

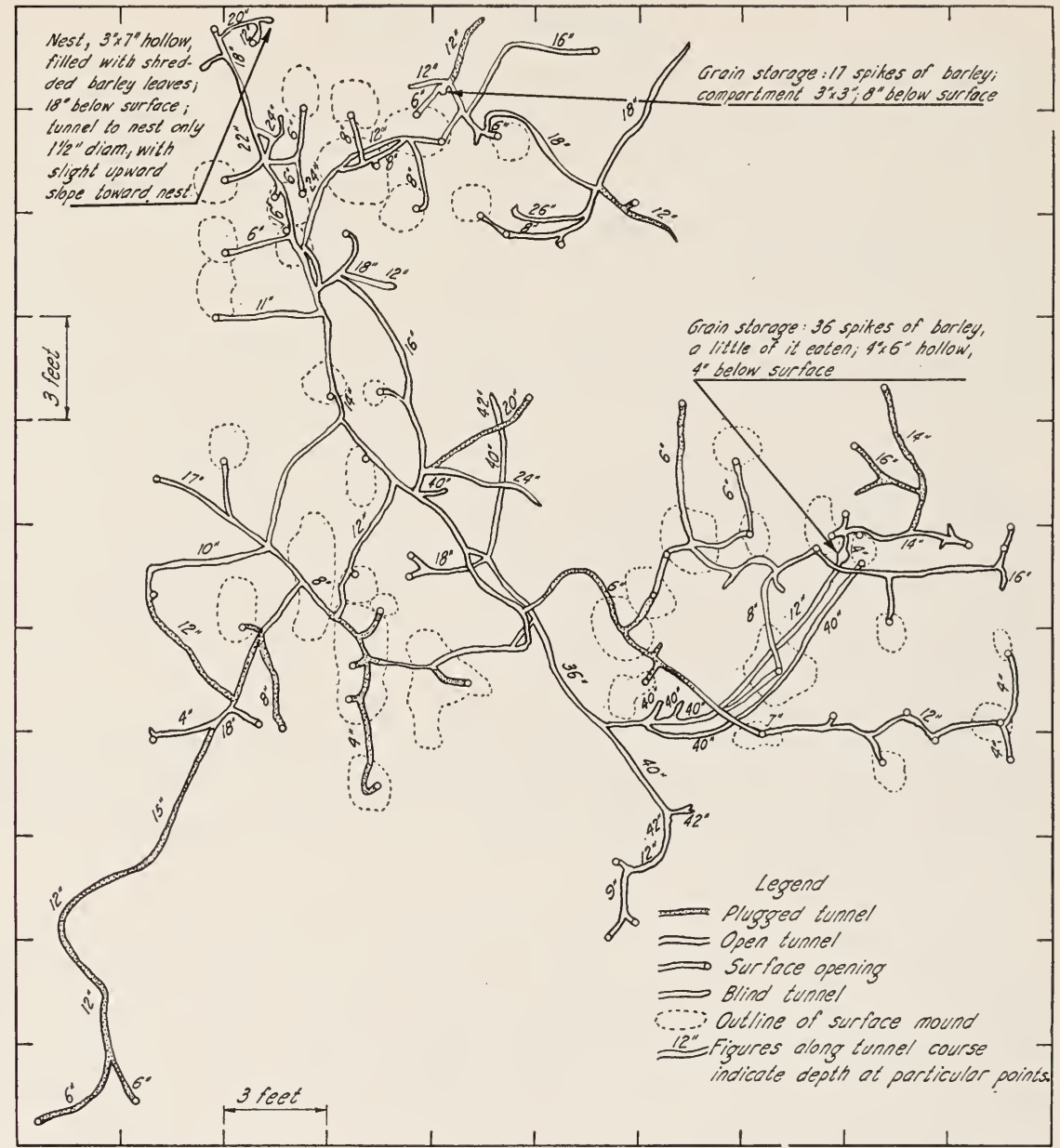

Fig. 12.-Plan of the burrow system of a pocket gopher; excavated on University Farm at Davis, October-November, 1934, by Elwood W. Veliquette.

the latter so that they die unless saved by bridge grafting (Hodgson, 1923). Gopher burrows in home gardens often divert the relatively expensive metered water. Burrows in the banks of ditches and canals may lead to breaks in the earthwork through which water is lost and adjacent lands are flooded, making expensive repairs necessary.

On wild lands gophers may be beneficial in the long run. Pasture lands cleared of them often show an immediate increase in the amount of forage available for livestock, but it is unknown whether this would continue for a 
series of years. On unplowed land gophers "cultivate" the soil, often turning over large portions of the surface in a single year. Whether their burrowings contribute to or serve to check erosion on slopes probably depends upon local conditions. The rich sediments of valley bottom lands have resulted from erosion at higher altitudes in past geologic time; to this process pocket gophers may have contributed.

\section{Methods of Control}

With persistence, pocket gophers may be effectively controlled and even eliminated over considerable areas. Control may be practiced at any season. Prompt attention to the first evidence of gopher work in a garden will often save valuable plants. Obviously the best time to

Pocket gophers can be controlled more successfully than any other rodent, because they advance their tunnel systems slowly and they do not usually travel far overland.

exercise control is before the young are born. Every female caught before the young are born means fewer gophers for the next season. Both trapping and poisoning are easiest as green vegetation starts in early winter or spring, when gophers are very active and the ground is soft.

When gophers are numerous in land that is to be used for truck crops or orchard, there should be a vigorous control program to reduce their numbers before planting. Then the land should be plowed with a subsoiler having the blades set for a depth of 18 to 24 inches to destroy all existing gopher tunnels. Thereafter new invasions by gophers can be recognized, and the animals destroyed promptly by traps or poison.

The methods used against pocket gophers are: (1) trapping; (2) poisoning; (3) gassing; (4) flooding; (5) exclusion; (6) encouragement of natural enemies. There is a common but mistaken idea that some kinds of plants are "gopher repellent." There is no reliable evidence that any kind of plant will keep gophers out of a garden.

Trapping. The traps used for rats, mice, and large mammals are not suitable for gophers, which must be caught in their burrows where space is limited. Many special gopher traps have been designed (fig. 13). These are of two kinds: those designed to spring when a gopher pushes against the flat trigger pan of the trap, and those operated by a bait trigger, moved when the gopher seizes the special bait.

Trapping is especially useful in gardens, orchards, small fields, and the banks of irrigation canals. In California, trapping is probably as effective as any other single method of gopher control. Traps are useful in following up and capturing individual gophers. The special gopher traps are safe to handle and require only a limited amount of skill and a little digging to place them. On one ranch near Davis a workman handled about 75 traps, set usually in pairs. These required about 5 hours daily to examine and reset as needed, and on 3 successive days took 38,40 , and 37 gophers, respectively.

The most successful and most commonly used trap in California is the Macabee (fig. 1 3, $A$ ), about $51 \frac{1}{2}$ inches long, and constructed of wire except for the trigger. The next most popular is the box type with a choker effect (fig. 
13, H). Many other types have been designed and marketed but none seems to have found any lasting demand. Some explosive traps or "gopher guns" have been made; but there is some hazard to the user, and their efficiency has not been proved.

The best "set" for the Macabee trap is in the main runway (fig. 14), and not in the lateral run leading to the surface mound. This requires the use of two traps per setting, one in each direction. But the results are quicker and much more certain, so that the catch per trap per day is greater than if only one trap is set in a lateral run, where it is often filled with dirt by the gopher. A lightweight shovel serves for digging down to the main run, and a 12 -inch, stout iron spoon is useful for finding the main run and placing the trap properly. The freshest mound should be selected, and the probable location of the main run determined by noting the angle of the dirt-plugged hole. The mounds are usually 6 to 15 inches distant from the main run, and the laterals nearly at right angles to it.

The procedure is as follows: push the handle of the spoon into the ground where the lateral is believed to be. If the handle enters an open lateral it will drop through the opening. If the lateral is filled loosely with dirt, the drop will be less noticeable but still plainly felt. If it is plugged tightly one must dig down a little distance with a shovel before probing again. If this fails, try a new mound. When a lateral is located, follow it down to the main run, which is always kept open by the gopher. With the shovel, clear a place so that a trap can be set in each direction (fig. 14). Clear out the main run with the spoon, disturbing it no more than necessary. Set the treadle, or pan, so that a light touch will spring the trap, and place the trap, jaws forward, well into the hole. A little loose dirt may be left in the bottom of the hole to cover the prongs and front end of the trap when the latter is pushed into place. Press the trap down firmly so that it will not slide backward if a gopher pushes against it. Many people cover the burrow with a clod or a handful of grass or alfalfa so that little light reaches the trap. A gopher instinctively closes all open burrows tightly to keep out natural enemies. A trap placed in an uncovered hole may be sprung by the dirt which the gopher pushes ahead in plugging the hole.

Each trap should have a light wire or cord attached so that it can be fastened to a stake or some other object to mark its location. This plan also prevents the trap from being dragged far back into the tunnel by a wounded gopher or being removed by a predatory animal when it contains a gopher. If conspicuous stakes 2 or 3 feet high are used, traps are less likely to be lost, should the field be cultivated while they are set. Stakes are essential to mark trap locations in alfalfa fields or truck patches, otherwise many will be lost. On a ranch where traps are used regularly it is well to have some distinctive kind of stake so that all the farm laborers will recognize gopher sets. For most efficient use of traps and results, each setting should be visited morning and evening, or oftener.

Occasional gophers prove difficult to trap. To capture such animals, take a Macabee trap and move the treadle forward about an inch and a half, placing the wire which carries the treadle below, instead of above, the two longitudinal wires. Cut off the wire trigger to meet this change. Then bend the treadle back- 

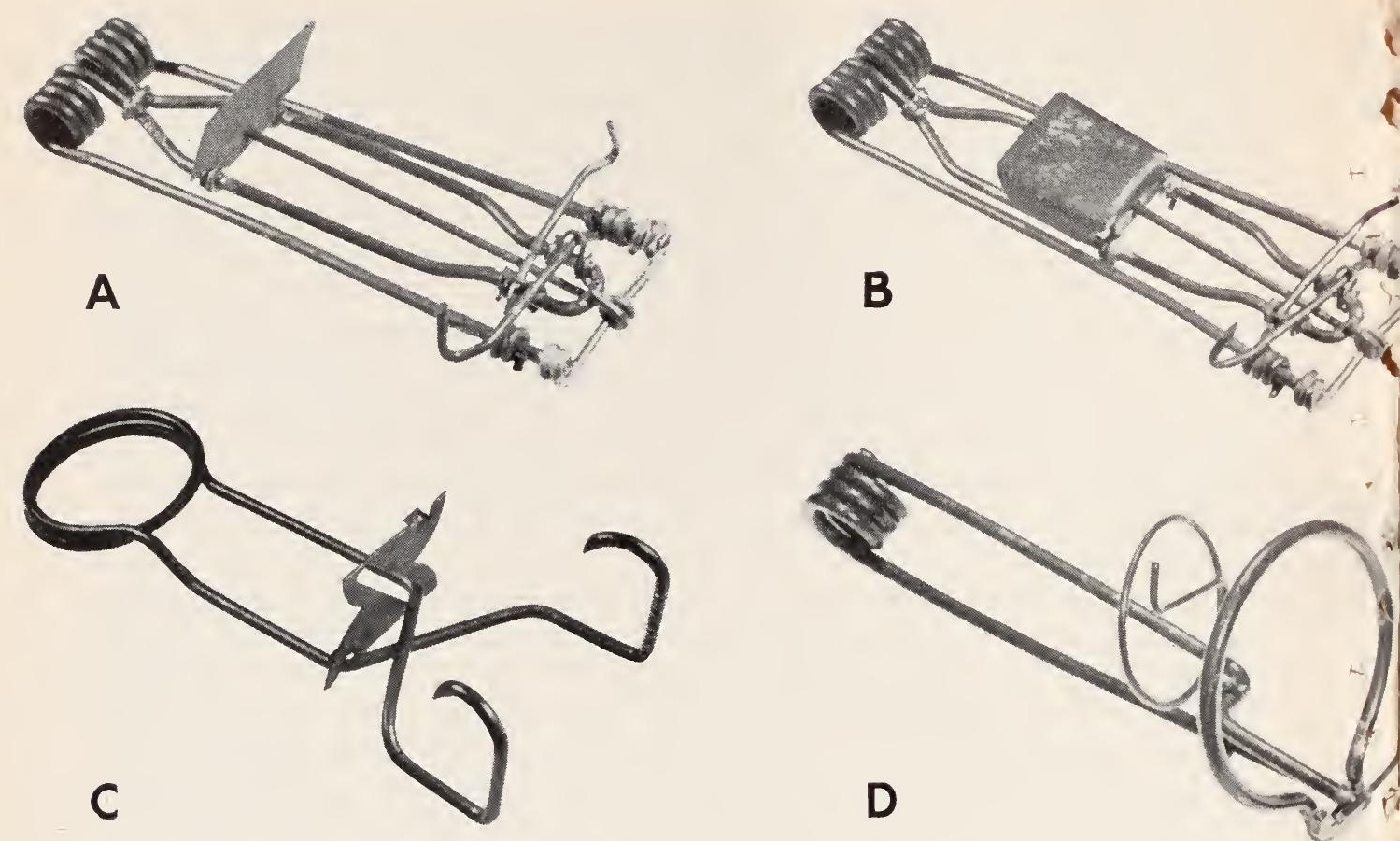

Fig. 13.-Traps for pocket gophers. All are shown as set, with front end (at right), which is to be put foremost into burrow. $A$, Macabee trap; $B$, modified Macabee trap, for moles and for gophers that are hard to trap; $C-G$, miscellaneous types; $H$, California pocket-gopher trap of wood.

ward at right angles to its former position so that it will lie parallel with the trap, instead of standing up at right angles to the runway (fig. 13, $B$ ). Set the trap so that it will spring easily. Put a bit of loose cotton under the treadle to keep out dirt, place the trap in the run, and cover the whole trap lightly with a thin layer of loose earth.

After having put out traps, tramp down or kick the tops off all mounds nearby so that on the next visit any new mounds will show where gophers remain and where further effort is needed.

Poison Baits. Pocket gophers may be killed in numbers by use of poison bait. Since their external cheek pouches or pockets are lined with fur, no poison can be absorbed there as with ground squirrels, and dependence must be placed on stomach poisons. Strychnine alkaloid or sulfate is effective for this purpose. The bait must be something relished by gophers and must be placed in the main runs with as little disturbance as possible; if placed on the surface of the ground it would not often be found by gophers and might be a menace to other animals, wild or domestic; and if put into laterals or open holes it may be buried or pushed out in the dirt. Root vegetables dusted with strychnine are the commonest bait used (formula 5). These baits are made of such size that they cannot be carried in the cheek pouches; the gopher must cut them first, and thereby is poisoned. Dried fruits (formula 6), grains (either hulled or crushed), and fresh alfalfa are used at times. It is no longer considered necessary to sweeten the material to disguise the taste. 

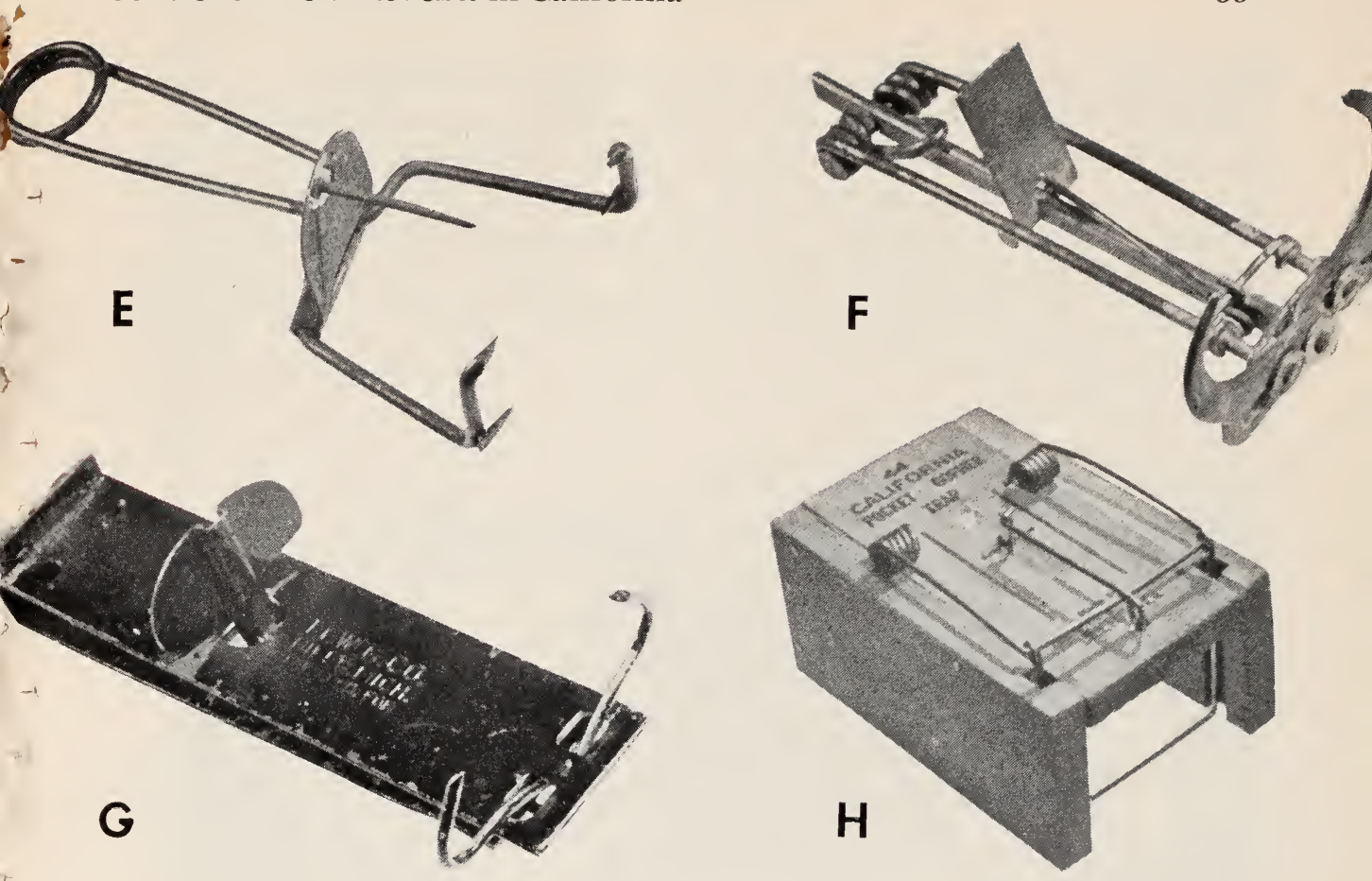

FORMULA 5

\section{Cut Baits for Pocket Gopher}

Cut baits of sweet potatoes, carrots, or parsnips . . . . . . . 4 quarts Strychnine (powdered), either alkaloid or sulfate . . . . . . 1/4 ounce

Cut the vegetables into pieces about $1 / 2 \times 1 / 2 \times 11 / 2$ inches. With a pepperbox or other sifting device dust the strychnine on the baits, a little at a time, meanwhile turning them over and over, until all are evenly coated. Put the baits in a covered container and use as soon as possible. Label, plainly, both the bucket and the sifter: POISON.

\section{FORMULA 6}

\section{Poisoned Raisins or Prunes for Pocket Gopher}

With a slender knife point insert a few crystals of strychnine sulfate into the center of each bait. The prunes should first be soaked for about 2 hours in water; if dried thoroughly after being poisoned, they will keep; such baits can be stored in a bottle or can and must be plainly marked POISON.

Baits of any kind are placed in main runways by use of a special probe (fig. 15), with which burrows can easily be located and baits inserted with a minimum of disturbance. The probe can be made by a blacksmith. The main shaft is of $1 / 2$-inch iron pipe, 33 inches long. A bluntly conical point of solid metal of the same diameter' as the pipe is welded to one end, and to the opposite end, a 12-inch length of $3 / 8$-inch steel rod. The free end of the rod is forged to make a slightly larger carrot-shaped tip about $1 / 2$ inch in diameter at the base, tapering to a sharp point. In loose or sandy soil the rod tip may be slightly larger; for hard earth the slight enlargement near the tip may be omitted. The side arm, 6 inches long, has a collar (and set screw) by which it is clamped to 
the pipe shaft. The side arm can be adjusted at suitable height on the probe shaft to apply downward pressure with either the hand or the foot.

To use the probe, sink the slender, sharp end into the ground between the rows of gopher mounds. Repeat this until the main tunnel is struck, at which time the tool will drop suddenly about 2 inches. The opening should then be enlarged, by rotating the probe or by using the opposite larger end, so that a poisoned bait may be dropped easily into the burrow. After putting in the poisoned bait, the hole made by the probe should be closed carefully by the

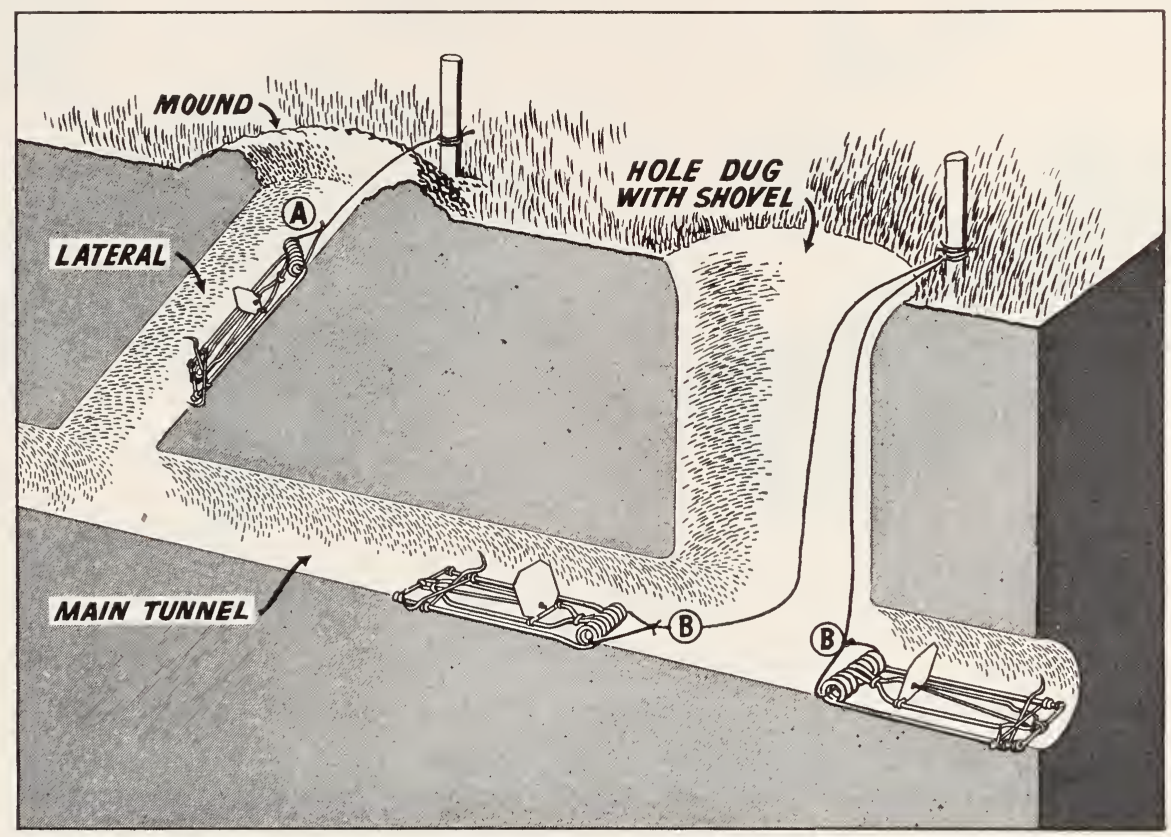

Fig. 14.-Two methods of placing traps for pocket gophers: $A$, single trap in lateral tunnel; $B$, hole dug with shovel, and two traps set in opposite directions in main tunnel. Each trap should be fastened by wire or cord to a stake tall enough to be seen easily in the field.

operator's heel. It is well to put 2 baits into each tunnel, at slightly separated places. As the work proceeds, the tops of all mounds should be trampled down or kicked off. It is then easy to locate new mounds made by gophers that escaped the previous treatment and to place new baits only where needed.

Experiment has shown that 40 per cent more baits are taken when inserted by a probe than when burrows are dug open with a spoon or shovel. The probe method is also much faster. A trained man, using this probe, can treat several hundred holes, over as much as 40 acres, in a single day. The probe is easiest to use when the soil is damp and soft down to the level of the main tunnels and less so when the ground is hard. It is unsatisfactory in sand; or in adobe that cracks when dry, since the probe then drops as easily into a crack as into a burrow. In finely cultivated fields the dry surface soil should be scraped back before closing the hole, which may be done with a clod of earth.

The best time to use the probe is in the fall during the first cool weather or just after the first good rains, and in the spring months. I3urrows are easier to 
locate when the mounds are conspicuous, before green vegetation becomes tall and abundant. The land should be gone over thoroughly at this season. Alfalfa fields, because of the abundant and continuous food supply, are sometimes more difficult to treat effectively than orchards or open fields.

Gophers are most apt to gnaw or girdle orchard trees during late summer, after the surface of the ground has become dry and green vegetation is scarce. Thus at the season when the gopher is doing the most serious damage, and speedy destruction is most to be desired, the probing method is least easy and the operator may have to dig down to the main runways to place poisoned baits. In a garden, nursery, or lawn where it seems desirable to use poisoned baits rather than traps, formula 5 or 6 may be employed.

In dry ground, where use of a probe is not practicable, the main runs of the gopher can be opened up in the same manner as for setting a trap. By use of a slender pointed stick, one of the poisoned baits is placed a foot back in each runway, which is then tightly closed. The hole should be opened 2 days later; if the bait is gone and the hole remains open, the gopher is probably dead.

Poisonous Gases. Poisonous gases are not often effective against pocket gophers. Factors which make the gas method less efficient are the extent of the burrow system, the chance for leakage of gas through the softer earth of laterals, the closeness of the main runs to the surface of the ground, and the fact that gophers may quickly plug off their burrows when a poisonous gas is detected and so escape destruction. Some workers have reported success with carbon disulfide or calcium cyanide (flakes or dust), but in general other methods are usually better. Exhaust gases from an automobile, which contain some carbon monoxide, may be used for gophers in the manner described for ground squirrels (page 21 ). Various gopher "bombs" have been offered for sale, which, when lighted and placed in the burrows, were supposed to generate a poisonous gas to overcome gophers. Their use has not proved effective and is to be discouraged.

Flooding. In most sections of California where irrigation is practiced, croplands and orchards are periodically flooded. On alfalfa, this is done regularly. At such times the gophers are either drowned or forced out by the incoming water. If their tunnel systems include runs in the levees, they may avoid the water by entering these. Some, driven out into the open, seek the higher borders of the field. At this time they may be easily killed by a good dog or by a stroke of the irrigator's shovel.

Exclusion. Small flower or vegetable gardens or orchards, adjacent to wild lands over which the gardener has no control, sometimes need special protection against the entrance of gophers either by burrows or by overland migration. A fence of small mesh wire or of sheet metal or concrete extending about 24 inches below the ground surface and about 10 to 12 inches above the ground will usually protect against gophers. In lighter soils greater depth may be desirable. If the fence is built to 36 inches above ground, it will also exclude rabbits.

Cementing ditches is effective where gophers are active in burrowing through the banks. A power company that had had much trouble with pocket 
gophers in a canal bank dug a vertical trench 4 inches wide and 6 feet deep lengthwise through the middle of the bank. The earth was loosened with a crowbar and removed with a narrow post-hole shovel. Then the trench was

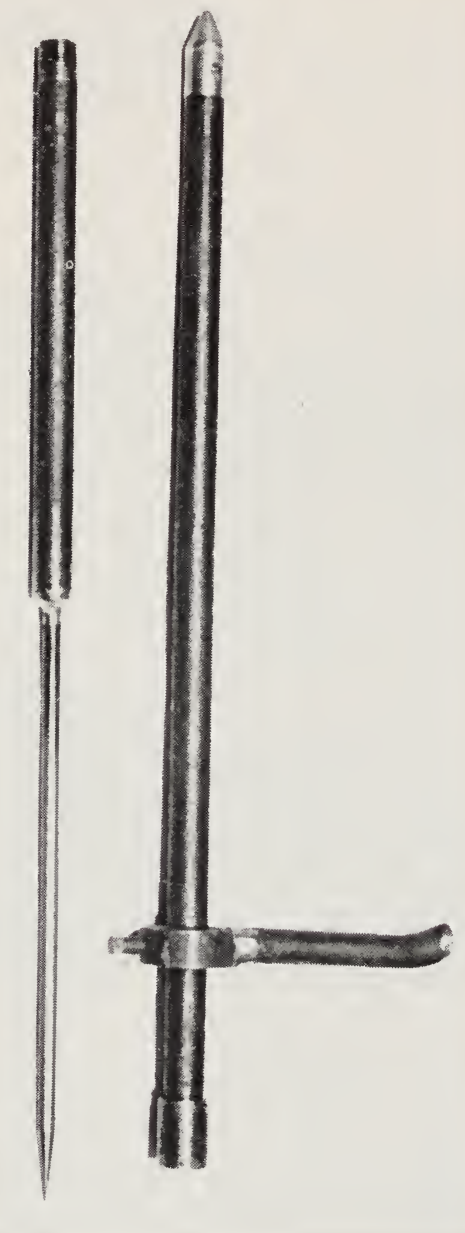

Fig. 15.-Probe for locating main tunnels of pocket gopher and inserting poisoned baits. The probe may be made in one piece, or it may be divided by use of a pipe coupling, as shown, for convenience in carrying when not in use. filled with a "lean" mixture of cement and sand. Cement was also used to protect a small irrigation ditch having a 7 -foot surface from gophers, weeds, and leakage. First a $7 / 8$-inch coat of 1 to 7 cement and then a $1 / 4$-inch surface layer of 1 to 3 cement was applied to the sides and bottom. Such costly preventive measures are advisable only where the usual control methods are ineffective.

Young trees may be protected against gnawing by gophers if a cylinder of wire netting (1-inch mesh or smaller) about 12 inches in diameter and 18 inches tall is sunk in the hole around the tree when it is planted; the top of the wire should be a little under the surface of the ground to avoid difficulty later in cultivating around the tree.

Trenching is successful for small-scale operations. A steep- or vertical-walled ditch 18 inches wide by 24 inches deep is dug around the plot that is to be protected against gophers. Open-topped 5gallon cans, spaced at intervals of 25 feet, are sunk so their tops are level with the bottom of the ditch. Gophers getting into the ditch will be likely to fall into the cans, from which they cannot escape.

Encouraging Natural Enemies. The barn owl and gopher snake are useful aids in gopher control. The owl nests in barns, steeples, palm trees, and holes in cliffs or earth banks. Its diet is almost entirely of rodents, often mainly of pocket gophers. After digesting a meal, an owl regurgitates the indigestible portions as a "pellet" dropped below its roost. Analysis of pellets from many roosts show that pocket gophers are often the chief item of diet (Smith and Hopkins, 1937; Evans and Emlen, 1947). One pair of owls may take 3 to 6 gophers daily when feeding their young. This owl rarely eats birds and never kills poultry. The gopher snake commonly eats gophers in fields and orchards, but sometimes takes eggs from wild birds or from henhouses. Every gopher eaten by either of these animals means one less for the farmer to catch. 


\section{MOLES}

Moles and gophers differ in structure and appearance; they are not even closely related. The moles are not rodents; they belong to an entirely different order, the Insectivora. Their habits too are different, and they require different methods of control. Yet because both

Moles should not be confused with pocket gophers, which do much more damage but are easier to control.

are garden pests and live underground, they are often confused with one another.

The mole (genus Scapanus; fig. 16) has a slender, conical snout, no external eyes or ears, small needlelike teeth, and forefeet with large palms and heavy claws. The silvery black fur is of velvety texture and is quite short. Unlike a pocket gopher, the mole has no cheek pouches of any sort.

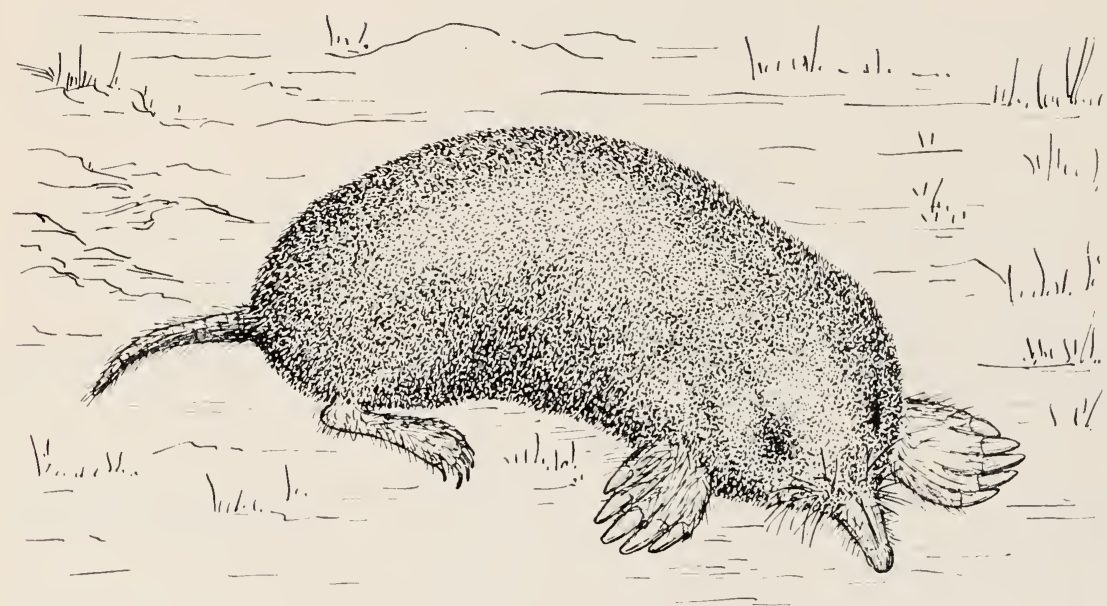

Fig. 16.-The mole. Its distinctive features are the slender snout, short needlelike teeth, greatly enlarged forefeet and claws, velvety fur, and short tail. The head-andbody length is about 5 inches, and the tail about $11 / 2$ inches. Compare with figure 9 .

Moles are common in the northwestern humid coast belt of California south to Monterey Bay; some live in the river bottoms of the lowlands and in other places with damp soils, as in foothill and mountain meadows, and locally in gardens and citrus groves of southern California. They are absent from much of the agricultural area of the state.

\section{Habits}

Two entirely different kinds of workings are made by moles: tunnels or runs just below the ground surface, and deep burrows; the first type is more extensive. In searching for food a mole moves along very close under the ground surface and pushes up a low rounded ridge of earth, leaving a tunnel or run below, through which the animal may travel once or repeatedly. The gopher's tunnels are much deeper and cannot be observed from above except at the entrances. The deep burrows of the mole, like the main tunnels of gophers, are farther below the ground surface; the earth from such excavations, instead 
of being pushed out of an open tunnel, is forced up from below, there being always a central core of loose earth, so that the surface of the mound resembles a miniature volcano (fig. 17). The runs and surface mounds disfigure lawns, golf greens, and flower beds. In making them the mole may loosen or uproot small plants or cut the roots of larger ones.

Moles partly compensate for this damage by eating soil insects and worms, which are their principal food. They also eat sprouting seeds and bulbs to a limited extent and they may cut the roots of plants when making their runs or tunnels.

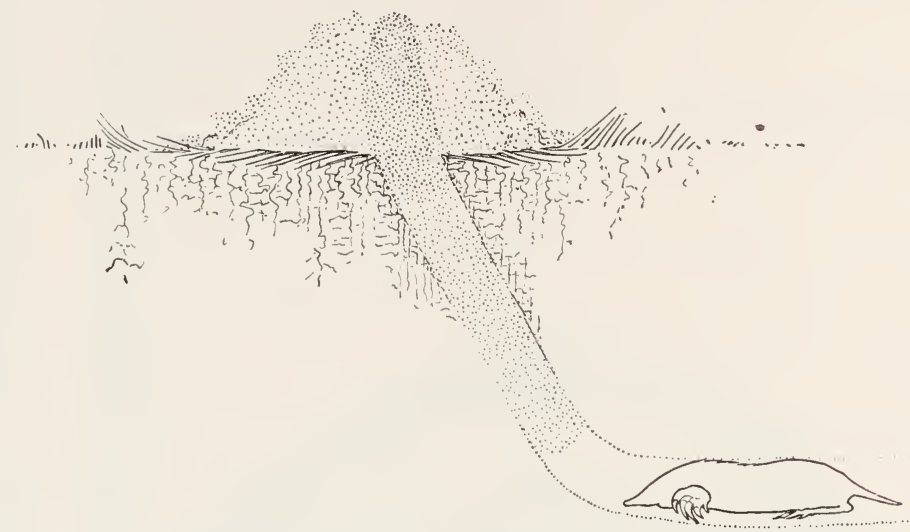

Fig. 17.-Deep tumnel and lateral of mole, showing how successive loads of earth are forced up from below to form an irregular surface mound without exposing the mouth of the lateral. Compare with figure 11 .

\section{Methods of Control}

Trapping. For one or a few moles, the persistent use of traps is recommended. The ordinary Macabee trap will sometimes catch a mole if set in a lateral tunnel, but the modified Macabee (fig. 13, B) is more effective. Several special types also are available (fig. 18). "Choker loop" traps are used successfully against moles in the Pacific Northwest, in the Middle West, and in Europe; but these usually are not available in California stores. In this type, two loops (or diamonds) of wire or metal are forced into the earth to encircle a run, and the trap is sprung by a trigger pan touching the top of the ridge. Two other traps commonly offered by the hardware trade in California are the Out-o'-Sight (with jaws) and the Reddick (with prongs). Both types are pushed down to straddle the surface runway of a mole; each has a trigger pan that is to be pressed against the top of the earth over the run. All these traps are released by the upward pressure of the mole's body against the earth over the run. The Out-o'-Sight is a "scissor-jaw" type, and the Reddick has several downwarddirected spears. The spring of the first causes the two pairs of jaws to clamp the animal firmly and fatally; the spears of the second are driven downward through the earth and into the mole's body. The choker loop is generally reported to be the most effective; the spear type, least so. The latter has the disadvantage of puncturing the mole's skin, which reduces its value if it is to be saved as fur.

To determine, before setting a trap, which runs are in use, press down the soil here and there on several runs; if a run is in use, the mole, in passing, will 
raise it again. Thereupon, press the soil down lightly once more and set a trap, pushing it down enough so that the trigger pan rests firmly against the earth over the run. Upon the next round, the mole's body will force the trigger upward and release the trap. In dry weather, wetting the ground over a run is reported to encourage a mole to return through the run; then a trap may be set.

Repellents and Gases. Lye, paradichlorobenzene ("PDB"), or naphthalene, introduced into mole runways, a teaspoon every 10 or $15 \mathrm{feet}$, is sometimes helpful in repelling moles (Scheffer, 1930). Calcium carbide (used for generating acetylene) has been tried for the same purpose in damp soil-with limited success. A little carbon disulfide poured or pumped into a deep runway will sometimes kill the mole tenant, but may injure or kill near-by plants. Exhaust gas from an automobile may be forced through a hose into a mole tunnel.

Poison Baits. Either ground meat or earthworms dusted with strychnine and placed in the runways have been tried for control of moles in England with some success.

\section{MEADOW MICE}

Meadow mice or voles (genus Microtus; fig. 19) are blunt-nosed, with small furry ears and a scantily haired tail, and are covered with soft dense fur that is blackish brown or grayish brown. When grown they measure 4 to 6 inches in head-and-body length, with the tail

Grain, hay, alfalfa, trees, root crops, and bulbs are occasionally damaged by meadow mice. The amount of damage they do varies by time and place.
$13 / 4$ to $23 / 4$ inches long. They live in fields or in ditchbanks covered with weeds or grass, in meadows, in grain or alfalfa fields, sometimes around haystacks, and in orchards with covercrops or where the grassy ground cover is allowed to remain.

Meadow mice live both on the surface of the ground and in burrows. Most species cut off the vegetation to form little pathways about an inch in breadth that extend here and there through the grassland. These connect with the many small burrows which the mice make in the soil (fig. 20). Such workings are often hidden when the grass cover is tall. When the presence of meadow mice is suspected, it may be necessary to part the grass tops and search beneath the cover. The number of mice present may be inferred by the amounts of freshly cut grass or of droppings to be seen in the runways.

Meadow mice may cut green vegetation (including alfalfa), injure standing grain, damage hay in loose cocks or stacks, gnaw the bark and roots of trees surrounded by grass and weeds, and eat root crops or bulbs. Alfalfa fields are occasionally damaged by meadow mice to the stage where no profit results to the farmer. The damage is irregular in amount, season, and place of occurrence. Periodic increases in meadow mice have been noted at certain places in California. They have increased in some recent years on farms near Tule Lake (Siskiyou County), in the delta region of Sacramento and San Joaquin counties, and locally elsewhere.

Preventive treatment, where it can be used, consists of clean cultivation. Orchards with covercrops should be watched for signs of damage by meadow 
mice, and steps taken at once to check the mice if necessary. Otherwise, clean cultivation in orchards and the removal of grass and weeds along fences, about farm buildings, and around piles of lumber, will reduce the shelter and food for these animals.

Meadow mice may be controlled either by traps or by poison. For small numbers the best plan is to use mousetraps baited with oatmeal, rolled oats, or bits of apple or carrot or other root vegetables, and set with the triggers of the traps across the runways. The traps will then be effective on mice running in either direction along the surface paths. Sometimes unbaited traps will suffice. Traps should be visited at frequent intervals, since these mice are active by day as well as at night and the efficiency of individual traps is increased by frequent attention.

When meadow mice are present in large numbers or over a large acreage, it is necessary to use poison. Formerly strychnine on alfalfa leaves was employed (formula 8), but recently zinc phosphide on rolled barley or oats or oat groats (formula 7 ) has been used with success.

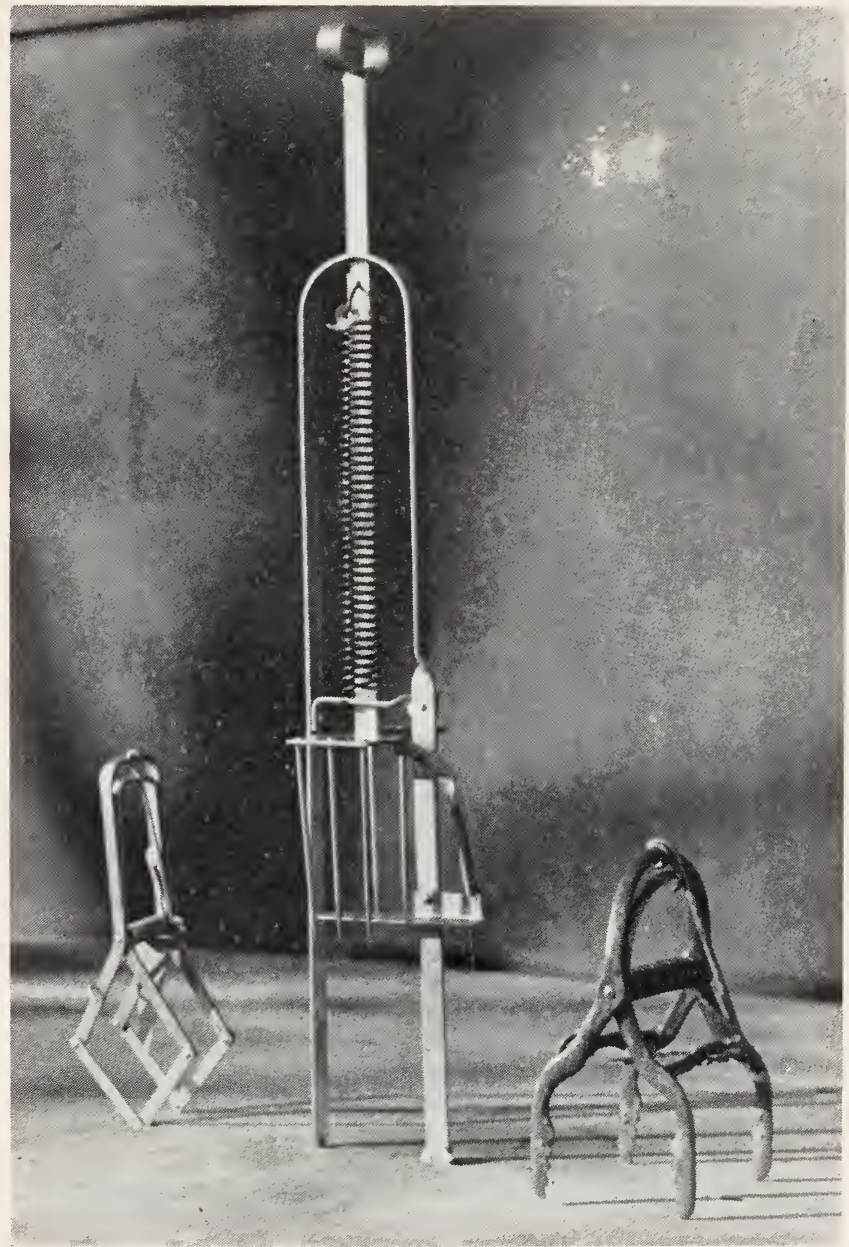

Fig. 18.-Mole traps, as set for use. Left, choker loop type (Nash); center, spear type (Reddick); right, lateral-jawed type (Out-o'Sight). 


\title{
FORMULA 7
}

\section{Zinc Phosphide on Grain for Meadow Mice}

\begin{abstract}
Steam-rolled barley, or oat groats, or whole oats . . . . . 100 pounds
Zinc phosphide . . . . . . . . . . . . . . . 9 ounces

Mineral oil, white . . . . . . . . . . . . . 16 fluid ounces
\end{abstract}

Mixing is best done in a steel drum containing baffle plates and mounted at an angle; turned by a crank, this device tumbles and mixes the materials well. The grain and poison should first be mixed dry until the kernels are evenly coated with the blackish zinc phosphide powder; then the mineral oil is warmed and added, and the drum turned again 30 to 50 revolutions. Mixing and handling the poisoned grain should be done out of doors. Workers should wear gloves and should avoid breathing gas fumes from the poisoned material. The formula may also be mixed in a cement mixer heated with a weed torch.

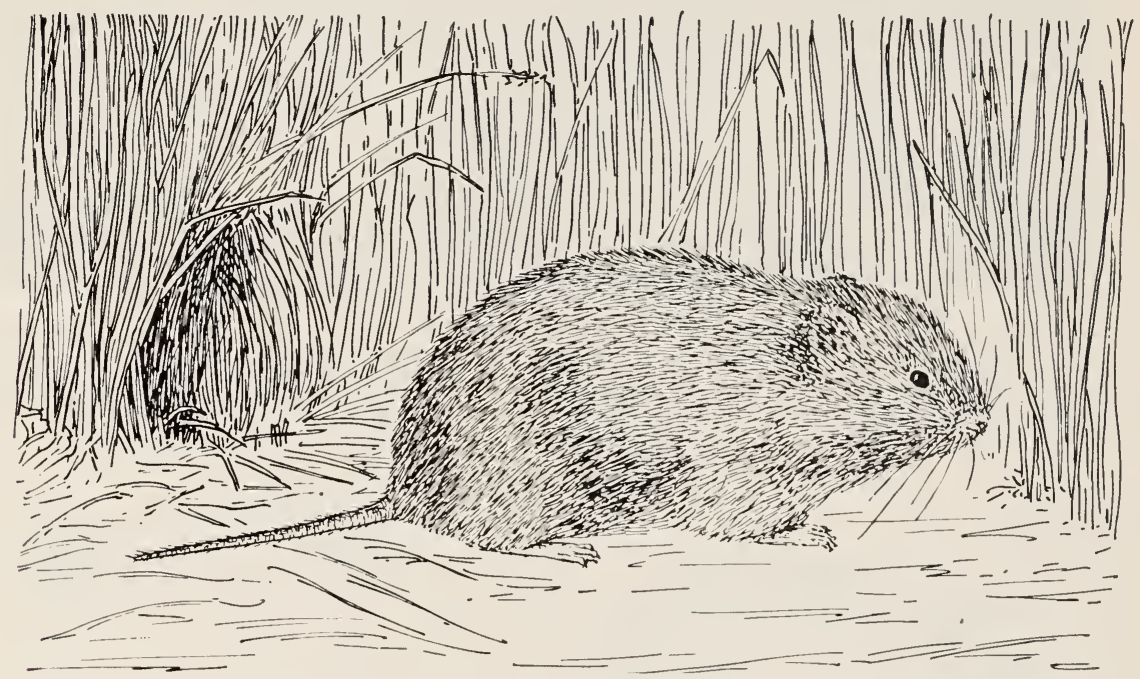

Fig. 19.-The meadow mouse. Its head-and-body length is 4 to 6 inches, and the tail $13 / 4$ to $23 / 4$ inches. The fur is dense and soft, reddish to blackish brown, and the ears are furry and partly hidden.

\section{FORMULA 8}

\section{Alfalfa Leaves with Strychnine for Meadow Mice}

\begin{abstract}
Green alfalfa leaves or steam-rolled barley . . . . . . . . . 100 pounds
\end{abstract} Strychnine alkaloid, powdered . . . . . . . . . . . . 1/4 ounce

Dissolve the strychnine in 2 quarts of water; sprinkle over the bait, turning the latter until all parts are moistened.

The poisoned bait-either grain or alfalfa-is broadcast by hand (gloves should be worn) so that it will scatter on the runways where it will be found by the mice. For heavy mouse infestations, amounts up to 15 pounds of grain bait are used per acre. One man can treat 15 acres a day, walking back and forth across the field and using marker stakes along the field borders to cover the field adequately and evenly. More than one treatment may be necessary per season when the mouse population is large. 


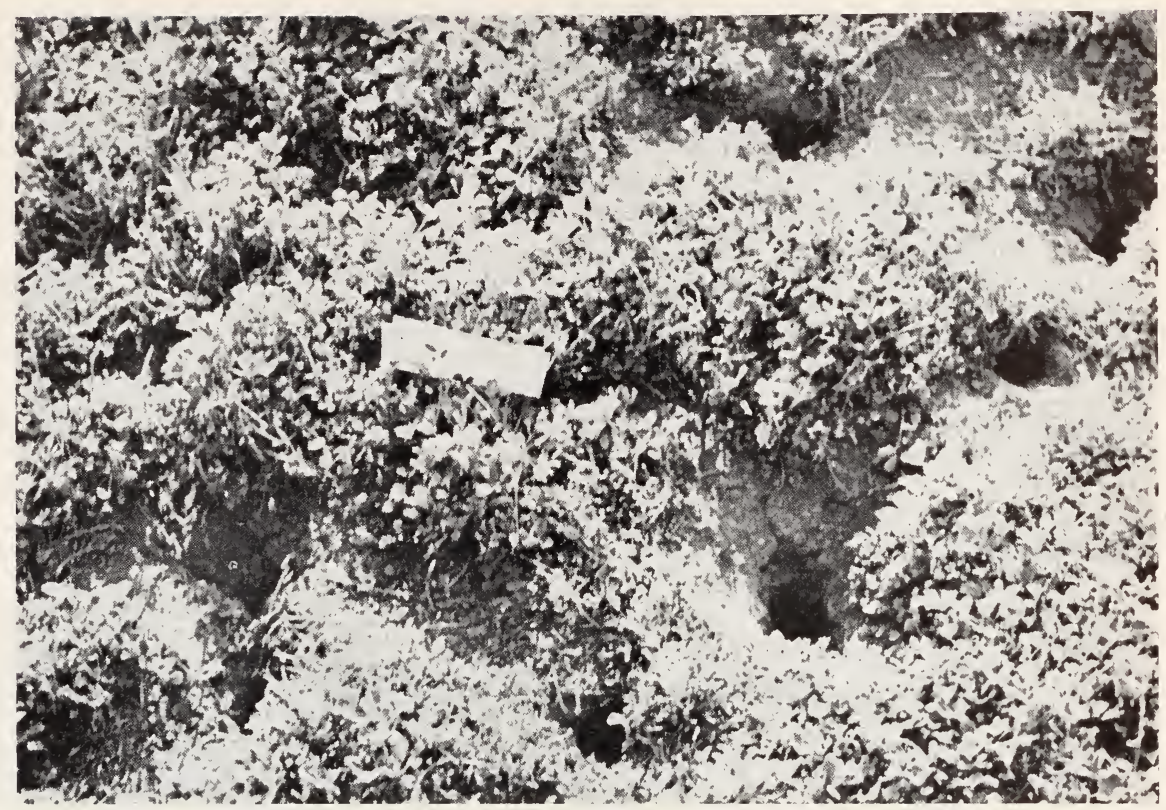

Fig. 20.-Burrows and runways of meadow mice in an alfalfa field heavily infested by these rodents. Many of the plants are killed by mice cutting off the roots, and quantities of the alfalfa stems are eaten as food. If not controlled, damage by these mice may be such that the grower will have no profit.

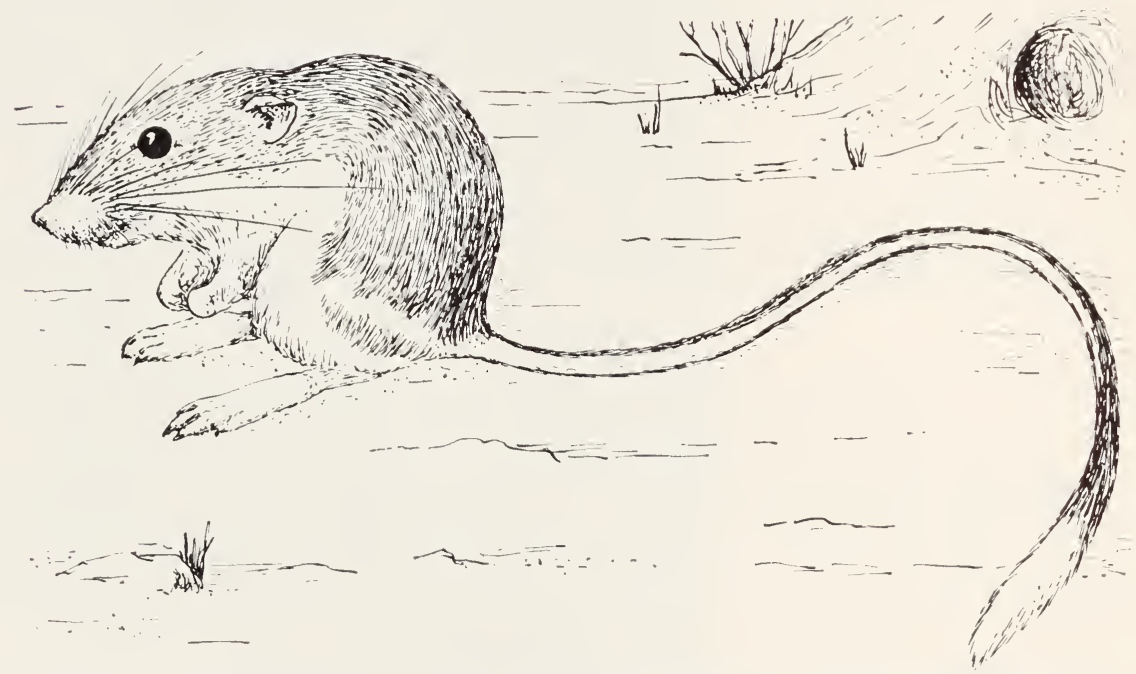

Fig. 21.-The kangaroo rat. Its head-and-body length is about 4 inches, and the tail about $71 / 2$ inches. The upper surface of the body is brown or tan and the underparts are pure white. There is a fur-lined cheek pouch on either side of the mouth. 


\section{KANGAROO RATS}

In lowland localities, where dry farming is practiced adjacent to wild land of desert or semidesert character, kangaroo rats (genus Dipodomys) sometimes damage grain crops. These distinctive rodents have long hind legs and feet, short small forefeet, long tufted tails, brown or tan backs, pure white underparts, and a pair of external cheek pouches (like those of pocket gophers; see fig. 21). The head and body are about 4 inches long and the tail about $71 / 2$ inches. Kangaroo rats live in short shallow burrows, in sandy or soft ground. The entrances to the burrows are usually closed with earth during the daytime. There is considerable fluctuation in their numbers. Over much of interior California these rodents are of slight importance, having been exterminated from many areas long under cultivation. When necessary, they may be easily controlled by use of strychnine-coated barley (formula 1, page 16) distributed near the burrows as is done for ground squirrels.

\section{MUSKRATS}

The muskrat (Ondatra zibethica) is a large aquatic rodent with a scaly, scantily haired tail and dense fur (fig. 22). The head and body measure $91 / 2$ to 12 inches and the tail is $71 / 2$ to 10 inches long. The animals live in marshy places about lakes or along streams, and feed on green

Muskrats have become rather widely distributed in California. Where abundant, they may damage irrigation structures. They may be controlled by trapping, and are often taken for their fur. vegetation and roots. They dig large burrows with underwater entrances and sometimes construct small "houses" of plant materials in quiet waters.

Originally muskrats were present in California only in a few scattered localities from Lassen County to Mono County east of the Sierra Nevada, and along the Colorado River on the Arizona boundary. Their numbers and the area occupied by them have been increased by man. The canal constructed to carry water from the Colorado River to the Imperial Valley formed a natural route for migration which they were quick to use. These large rodents are now fairly abundant and sometimes damage canals and ditches of the Imperial Valley. Their burrows in the banks sometimes contribute to causing breaks.

Muskrats earlier were transplanted into the Kern River and canals about Bakersfield and into lakes west of Santa Maria. They are present in Mendocino and Sonoma counties on the Russian River, and near Sebastopol; in Humboldt County near Prairie and Redwood creeks and Burnt Ranch; and in Del Norte County in Smith River and Lake Earl. In the Sacramento Valley they now occur in Butte, Glenn, Sacramento, and Sutter counties. They also occur in the Shasta River, Siskiyou County. Muskrats escaped in 1933 or earlier from a fur farm near McArthur, Shasta County, and have spread until they now occur from near Redding eastward and northward in many parts of Modoc, Shasta, and eastern Siskiyou counties (Storer, 1937; Twining and Hensley, 1943).

Muskrats now are common enough to provide considerable income for trappers. From 1939 to 1942 trappers reported taking approximately 7o,ooo 
muskrats annually with.a fur value of around $\$ 72,500$, which is about two thirds of the total income from fur for all of California.

In the eastern United States, where irrigation is not practiced, muskrats cause no particular damage to agriculture; but wherever irrigation or drainage canals are needed these animals are likely to cause trouble by tunneling into levees or ditchbanks.

Where muskrats must be prevented from damaging irrigation structures, no. 1 steel traps should be set in burrows or-better-on the characteristic "feeding mounds" in water 2 to 3 inches in depth, and should be partly sunk in the bottom material. The trap chain should be passed over a slender pole

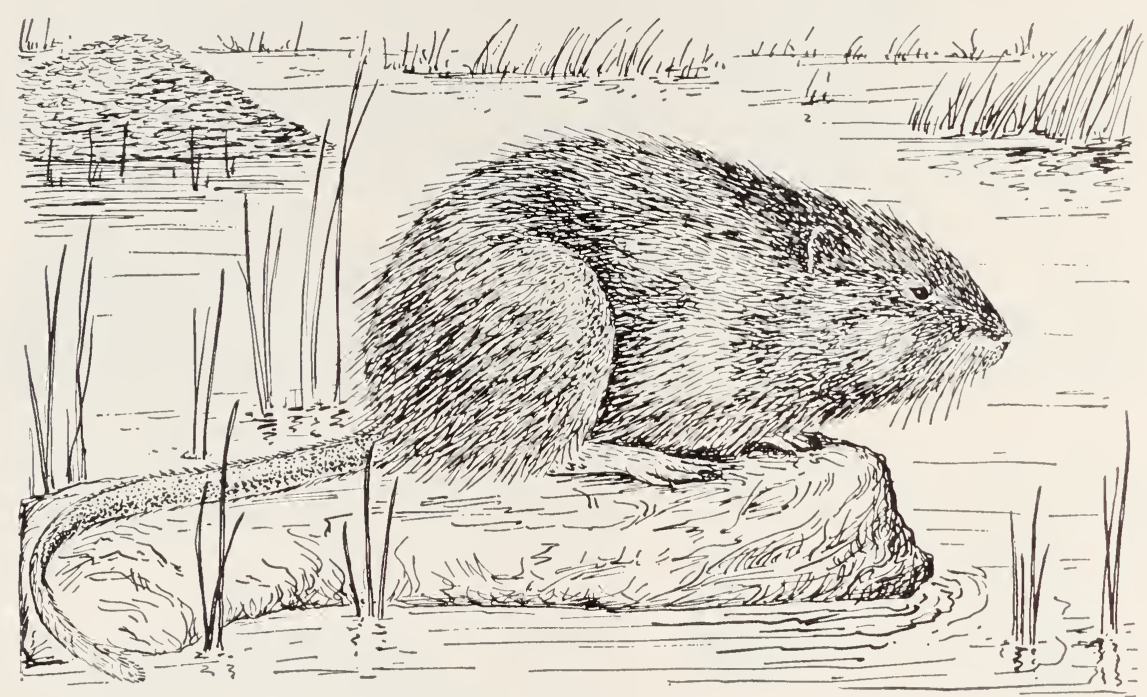

Fig. 22.-The muskrat. Its head-and-body length is $91 / 2$ to 12 inches, and the tail $71 / 2$ to 10 inches. The tail is narrow, higher than wide, and scaly. The fur is dense, soft, and brownish. A muskrat "house" is shown at the upper left.

driven into the bank but leaning over the water; the outer end of the pole should have a crosspiece at the top to prevent the trap chain from being slipped off. A trapped muskrat will usually dive into deep water, so that the chain slides along the pole and the animal is quickly drowned. Some trappers use a bait of parsnip, sweet potato, carrot, or other root vegetable, suspended on a small stick so as to be about a foot over the trap site; but many use no bait whatever. Other methods of capture have been described by Lantz (1923) and Storer (1937).

In the past, ditch owners have employed trappers under permit to reduce muskrats, but this has not been satisfactory because trappers did not remain long enough to reduce the animals to small numbers. Encouragement of trapping for fur, followed by employment of paid and supervised trappers where necessary, will give greater protection and ensure that the rodents will do no serious damage.

Muskrats near Bakersfield were controlled by pumping carbon disulfide into burrows at a season when water had been withdrawn from the canals and the tunnels were easily found. 


\section{RABBITS}

Rabbits (fig. 23) comprise two major types: the hares (genus Lepus), represented by the jack rabbits and the snowshoe rabbits that live entirely aboveground, make no nests, and bring forth their young fully covered with fur, with their eyes open, and able to move

Jack rabbits and cottontails, and sometimes brush rabbits, damage or destroy crops and trees. Control measures are limited because the cottontail and brush rabbits are protected as game over most of California. about at once; and the true rabbits, including the cottontail and brush rabbits (genus Sylvilagus), that dwell in dense cover, under stone piles and brush, or in burrows, and leave their young in the nest for a period of growth. More detailed discussion of rabbits in California will be found in Orr (1940).

\section{Black-tailed Jack Rabbits}

The common jack rabbits (Lepus californicus) occupy the lowland, foothill, and desert portions of California, and are sparsely represented in the humid coast region. They are absent from the higher mountains above the yellowpine belt, but present in the northeastern plateau counties. They depend upon speed and dodging to escape enemies. They live chiefly in open places, seldom inhabiting dense brush or thick woods. The average litter is about four; young are in evidence through much of the year but the greater number are produced in the spring months.

Jack rabbits make no nests, but individuals often have a more or less regular retreat or "form" beneath a bush where the animal is somewhat sheltered from the full heat of midday sun, and yet can watch for the approach of enemies.

Their food includes a wide variety of plants, both wild and cultivated, the latter including grain, alfalfa, various truck and field crops, and at times the bark and tender shoots of small orchard trees. Indeed, one of the commonest complaints is of the difficulty in getting new orchards or vineyards started on areas adjacent to lands where jack rabbits are common.

Formerly jack rabbits were enormously plentiful, especially in the San Joaquin Valley and on the flatter areas of southern California. Many spectacular rabbit drives were held; most of the human population of a district would turn out and surround a territory several miles in extent, driving the rabbits toward a central corral bordered by wing fences. After being concentrated in such an enclosure, the rabbits were clubbed to death by the hundreds and even thousands.

Drives and other measures have reduced the population far below the earlier numbers, yet there are still enough jack rabbits in some places to do considerable damage to the more intensive agriculture of the present day. Their numbers vary considerably from year to year. Farmers should watch these animals on their land, because, in years when they are abundant, crop damage may be severe. Overgrazed lands tend to have larger jack rabbit populations than areas on which the grass cover is higher. 


\section{Snowshoe Rabbits}

In the higher parts of the Sierra Nevada and in the northeastern plateau region of California, there are two kinds of rabbits adapted to living on or in the snow during the winter months: the large white-tailed jack rabbit (Lepus townsendi sierrae) and the smaller snowshoe rabbit (L. washingtonii); both are hares. These, like the black-tailed jack rabbits, are surface dwellers. Their feet being densely covered with long fur, they can travel readily on snow. The tail of the snow-inhabiting rabbits is always white, and the animals themselves are white in winter. These animals live where there is little intensive agriculture; they occasionally nibble the twigs and bark of apple trees during the winter months, and the snowshoe rabbit damages young forest trees.

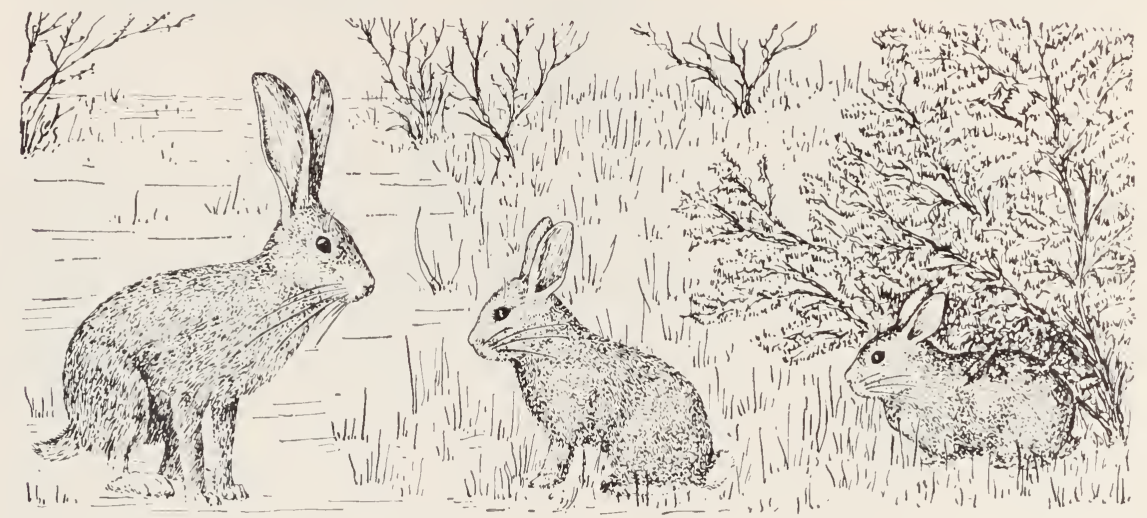

Fig. 23.-Common California rabbits. At the left is a black-tailed jack rabbit; the head-andbody length is 18 to 20 inches, and the ears are about 6 inches long. It lives mainly in open country. The rabbit in the center is the common cottontail; its head-and-body length is about 13 inches, and the ears are about 3 inches long. Cottontails inhabit streamside thickets and pastures. At the right is a brush rabbit. Its head-and-body length is about 11 inches, and its ears are about $23 / 4$ inches long. This rabbit lives under foothill chaparral and bushes.

\section{Cottontail and Brush Rabbits}

These true rabbits occur over the lower altitudes in California. Cottontails (Sylvilagus audubonii and $S$. nuttaltii) are more common in stream-side thickets and pastures; brush rabbits (S. bachmani) on brushy and chaparralcovered slopes in the hill country. Little is known about their rate of increase or manner of caring for the young. The litters are small, averaging about 4 , and are usually produced in the spring months. Both of these rabbits will feed upon cultivated crops of garden and field.

These rabbits are classed as game and, over most of California, may be hunted only between November 15 and December 31 . In the southern part of the state (Districts $4,41 / 8,43 / 4,19$, and 21 ), they may be taken at any time. The California Fish and Game Code provides that owners, tenants of land, or their agents may kill rabbits on their properties at any time in any part of the state, but rabbits so killed may not be transported or sold during the closed season. 


\section{Rabbit Control}

Rabbits are not difficult to control on small areas but present greater difficulty on large ranches. The methods used are: (1) exclusion, (2) shooting, (3) repellents, (4) trapping, (5) poisoning, and (6) encouragement of natural enemies.

Exclusion. A fence of mesh not greater

Exclusion is the best means of control on small areas, but other methods must be used on large acreages.

sages under the buried portion. Such a fence, if constructed of poultry netting (although a heavier-mesh fence is better) and combined with barbed wire above, will often serve as a stock fence for horses and cattle. Sheep and hogs, however, are apt to damage a light wire fence, and hogs especially may root at the base of such a fence and so destroy its effectiveness. Neither jack rabbits nor cottontails will ordinarily jump over a 24 -inch fence. But a jack rabbit when pursued by a dog may do so, particularly if the fence does not have closely spaced barbed wires above. Such a protective fence must, of course, be provided with tight-fitting gates and with sills or other means for making sure that rabbits cannot dig below the bottom rails of gates. The gates must be kept closed except when vehicles or persons are passing through.

Small spring-closing gates are useful in many places. A fence for exclusion is best for small flower or vegetable gardens, especially those adjoining large areas of pasturage, grain, alfalfa, or wild land. Any high-priced crop such as a small field of seed stock warrants the type. of fencing here described. If such a fence is constructed there will be almost no damage by rabbits. When a small plot of ground needs to be enclosed for only a few months, light stakes may be used to support the wire, the bottom of which is buried in a furrow; then, after the crop has been harvested, the wire and stakes may be removed to permit the use of cultivating machinery.

Around large acreages of farmland, provision of rabbitproof fencing is ordinarily impractical. The large rectangular mesh used as the lower part of a stock fence, where sheep or hogs are being pastured, has openings of a size that permits the passage of rabbits. Fencing for large areas with wire of strength adequate to restrain livestock and of mesh sufficiently small to exclude rabbits will ordinarily cost $\$ 1$.oo or more per rod for the wire alone.

Over many years, farmers in California have used individual mechanical protectors to guard the trunks of young orchard trees against damage by rabbits. Earlier, thin slabs of yucca and other veneer materials were employed. Ordinary sacking has been tied around trees with effective results. Poultry netting of 1-inch mesh, 20-gauge galvanized wire, 18 to 24 inches in width, cut into strips 12 to 18 inches long and formed into cylinders around young trees, is a common means of protection. Such cylinders should be braced so that rabbits cannot press them against the trees and gnaw at the bark between the wire meshes. A fine-mesh wire or hardware cloth would also protect against meadow mice, especially if pressed down into the ground at the lower edge. 
Shooting. Rabbits may be effectively controlled by shooting. They feed mainly in the early morning, late afternoon, and dusk of evening, when a gun is most effective; but they may feed also at night, so that this method is not entirely successful. Ranchers troubled by numbers of cottontails may obtain some relief by inviting sportsmen to hunt over their lands during the open season. On certain ranches spring hunting of jack rabbits is promoted; the hunter thereby obtains some sport at a season when other game cannot be shot, and the rancher some reduction of jack rabbits. Such hunting, however, will seldom clear a ranch of the animals. Reduction of jack rabbits in the spring is of especial benefit in limiting the number of young which might otherwise be produced. Jack rabbits have been hunted for market use, and this aids in reducing their numbers, but there is some danger of contracting the disease tularemia from handling wild rabbits. Any person skinning wild rabbits for fur or food is advised to wear rubber gloves.

Repellents. Various repellent substances have been used to prevent rabbits from gnawing the bark and twigs of trees and vines. An adhesive whitewash has some value. A strychnine-poisoned wash (formula 9) has been used in Idaho to protect young orchards. It should not be used where domestic animals are present.

\section{FORMULA 9}

\section{Poison Wash to Protect Young Trees against Rabbits}

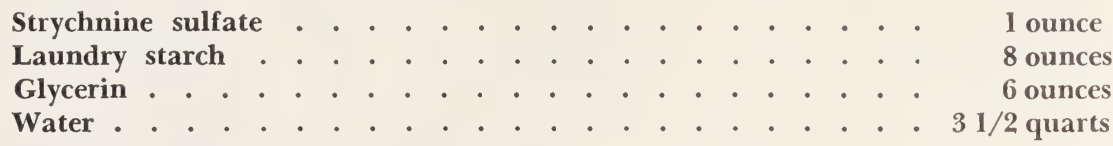

Prepare the laundry starch by mixing cold and then boiling in 1 pint of water. Dissolve the strychnine in the remaining water by boiling. Add the paste and glycerin. Cool and paint on trunks of trees. Do not admit domestic animals to orchards where this poison wash has been applied.

Fresh blood, daubed on young trees, has been used as a repellent, but results are often unsatisfactory. Sulfurized linseed oil as a repellent has served well in some cases, but in other trials in California it burned the bark and killed orchard trees so that its use cannot be recommended. Laths dipped in sulfurized (linseed) oil and driven in a circle about young trees are reported to be an effective repellent. Repellent 96 A sold by the U. S. Fish and Wildlife Service, Pocatello, Idaho, is a solution that seems to give protection to trees when applied during the dormant season.

Trapping. The jack rabbit drives of earlier years may be considered to have constituted a type of trapping. In the Middle West and East, cottontails are sometimes captured in a special box trap known as the Wellhouse (Lantz, 1924). A permanent rabbit trap, constructed with a horizontal run of sewer tile 6 inches in diameter and 4 feet long leading into a vertical $12 \times 6$-inch tile $\mathrm{T}$, with a heavy cover, has been used in Kansas. The entrance, surrounded by stones and brush, gives a natural appearance. Such traps may help in capturing cottontails in orchards. 
Poisoning. Use has been made of poison against jack rabbits in districts where ranches are scattered and the human population is sparse. Ordinarily, it should not be employed against cottontails or brush rabbits because these animals have value as game.

The poisoned bait may be any material relished by rabbits, such as alfalfa leaves, grain heads, or oats. Since rabbits, like many other animals, both wild and domestic, are fond of salt, poisoned salt has also been used.

If any of these poisoning methods are deemed necessary, the person responsible for the poisoning operations should make certain that all necessary precautions are taken to prevent domestic animals, harmless wild animals, and human beings from being endangered. For example, on stock ranges where poisoning has to be employed because jack rabbits are so numerous as to reduce the pasturage, substantial fenced pens excluding livestock but permitting jack rabbits to enter, have been used for the exposure of poisoned materials. Before poisoning, clean prebait-that is, bait material without poisonshould be offered to get the animals used to feeding at the site and make certain that the poisoned bait material will be taken when provided later.

In the event that the owner or tenant of land is having difficulty with rabbits which cannot be solved by any of the methods indicated above, it is recommended that he consult the agricultural commissioner or the farm advisor of his county as to the most appropriate methods to use.

Encouraging Natural Enemies. The red-tailed hawk and golden eagle both feed upon rabbits, and the gopher snake is known to capture small ones. These and other natural enemies that subsist on rabbits and rodents are valuable aids to the farmer. 


\section{LITERATURE CITED}

More detailed information on technical matters relating to rodents and their control will be found in the references listed below. The books and periodicals may be consulted at many libraries.

BECKER, E. M.

1940. An effective ground squirrel trap. California State Dept. Agr. Bul. 29: 152. 1 fig.

BERRY, C. E.

1938. Methyl bromide as a rodenticide. California State Dept. Agr. Bul. 27: 172-80. 5 figs.

BURNETT, W. L.

1932. The action of strychnine on the Wyoming ground squirrel Citellus elegans. Colorado Agr. Exp. Sta. Bul. 384: 1-19.

Crafts, A. S.

1936. Some effects of thallium sulfate upon soils. Hilgardia 10: 375-98. (Out of print.)

DIXON, JOSEPH.

1925. Food predilections of predatory and fur-bearing mammals. Jour. Mammalogy 6: 31-16. 1929. The breeding season of the pocket gopher in California. Jour. Mammalogy 10: 327-28.

Evans, F. C., and J. T. EmLen, Jr.

1947. Ecological notes on the prey selected by a barn owl. Condor 49: 3-9.

Grinnell, Joseph, and Joseph Dixon.

1918. Natural history of the ground squirrels of California. California State Comm. Hort. Monthly Bul. 7: 597-708. 5 pls. 30 figs. (Out of print.)

Grinnell, Joseph, and T. I. Storer.

1924. Animal life in the Yosemite. xviii +752 p. (See especially p. 134-43.) University of California Press, Berkeley, Calif. (Out of print.)

Hodgson, R. W.

1923. Saving the gophered citrus tree. California Agr. Exp. Sta. Cir. 273: 1-19. (Out of print.)

Horn, E. E., Justus C. Ward, James C. Munch, and F. E. Garlough.

1936. The effect of thallium on plant growth. U. S. Dept. Agr. Cir. 409: 1-8.

Howell, A. H.

1938. Revision of the North American ground squirrels. U. S. Dept. Agr., Bur. Biol. Survey, North American Fauna 56: 1-256. 32 pls. 20 figs.

Hull, T. G.

1941. Diseases transmitted from animals to man. 2 d ed. 403 p. C. C. Thomas, Springfield. 111.

JACOBSEN, W. C.

1923. Rate of reproduction in Citellus beecheyi. Jour. Mammalogy 4: 58.

LANTZ, D. E.

1917. Destroying rodent pests on the farm. U. S. Dept. Agr. Yearbook 1916: 381-98.

1923. The muskrat as a fur bearer with notes on its use as food. U. S. Dept. Agr. Farmers' Bul. 869: 1-20. (Revised.)

1924. Cottontail rabbits in relation to trees and farm crops. U. S. Dept. Agr. Farmers' Bul. 702: 1-14. (Revised.)

LINSDALE, J. M.

1946. The California ground squirrel. 475 p. 140 figs. University of California Press, Berkeley, Calif.

Miller, M. A.

1946. Reproductive rates and cycles in the pocket gopher. Jour. Mammalogy 27: 335-58.

OrR, R. T.

1940. The rabbits of California. California Academy of Sciences Occasional Papers 19: 1-277. 10 pls. 30 figs.

SCHEFFER, T. H.

1930. American moles as agricultural pests and as fur producers. U. S. Dept. Agr. Farmers' Bul. 1247: 1-20. (Revised.) 
Smitil, C. F., and C. L. Hopkins.

1937. Notes on the barn owls of the San Francisco Bay region. Condor 39: 189-91.

STORER, T. I.

1930. Summer and autumn breeding of the California ground squirrel. Jour. Mammalogy 11: $235-37$.

1937. The muskrat as native and alien. Jour. Mammalogy 18: 443-60. Also in: California Fish and Game 24: 159-75. 1938.

Tivining, Howard, and A. L. Hensiey.

1943. The distribution of muskrats in California. California Fish and Game 29: 64-78. 
